\title{
Geochemistry of the Rio Espinharas hybrid complex, northeastern Brazil
}

\author{
T.F.C. Campos ${ }^{\mathrm{a}, *}$, A.M.R. Neiva ${ }^{\mathrm{b}}$, L.V.S. Nardi ${ }^{\mathrm{c}}$ \\ ${ }^{a}$ Department of Geology, Federal University of Rio Grande do Norte, CP 1639 59072-97 Natal, RN, Brazil \\ ${ }^{\mathrm{b}}$ Department of Earth Sciences, University of Coimbra, 3000-272 Coimbra, Portugal \\ ${ }^{\mathrm{c}}$ Institute of Earth Sciences, Federal University of Rio Grande do Sul, 91501-970 Porto Alegre, RS Brazil
}

Received 27 November 2001; accepted 10 July 2002

\begin{abstract}
The Rio Espinharas pluton, northeastern Brazil, belongs to the shoshonitic series and consists mainly of syenogranite, quartz-monzonite and porphyritic quartz-monzonite, but diorite, quartz-monzodiorite, quartz-syenite and microsyenogranite also occur containing microgranular enclaves, except for the diorite. Most variation diagrams of rocks, amphiboles, biotites and allanites show linear trends, but $\mathrm{K}, \mathrm{Zr}, \mathrm{Sr}$ and $\mathrm{Ba}$ of rocks display curved scattered trends. The rocks ranging from diorite to syenogranite define a pseudo-errorchron and have similar REE patterns. Syenogranite and microsyenogranite are derived from two distinct pulses of granite magma with initial ${ }^{87} \mathrm{Sr} /{ }^{86} \mathrm{Sr}$ ratio of $0.7083 \pm 0.0003$ and $0.7104 \pm 0.0007$, respectively. Modelling of major and trace elements shows that the syenogranite evolved by fractional crystallization of plagioclase, microcline, edenite, biotite and titanite, whereas quartz-monzonite, porphyritic quartz-monzonite, quartz-monzodiorite and quartz-syenite resulted from simple mixing between an upper mantle-derived dioritic magma and the upper crust-derived syenogranite magma. Dioritic enclaves are globules of a mafic magma from the upper mantle.

(C) 2002 Elsevier Science B.V. All rights reserved.
\end{abstract}

Keywords: Hybrid rocks; Granites; Microgranular enclaves; Geochemistry; Rb-Sr isotopes

\section{Introduction}

Magma mixing is an accepted mechanism for the origin of microgranular enclaves (e.g., Frost and Mahood, 1987; Poli and Tommasini, 1991; Castro et al., 1991; Zorpi et al., 1991; Barbarin and Didier, 1992; Erlburg, 1996; D’Lemos, 1996; Maas et al., 1997; Collins et al., 2000; Silva et al., 2000; Waight et al., 2001) and for the origin of large intrusions (e.g.,

\footnotetext{
* Corresponding author.

E-mail addresses: tcampos@geologia.ufrn.br (T.F.C. Campos), neiva@ci.uc.pt (A.M.R.Neiva), lavro.nardi@ufrgs.br(L.V.S. Nardi).
}

Neves and Vauchez, 1995; Collins, 1998; Barnes et al., 2001). This process ranges from magma mingling when original components maintain most of their characteristics, through partial mixing with the production of a heterogeneous hybrid magma to complete and homogeneous mixing (D'Lemos, 1996). On a large scale in plutonic systems, hybrid rocks are expected to be heterogeneous due to high viscosity contrasts, slow rates of chemical diffusion, fast cooling rates and limited convection if they are derived by mixing of two magmas with distinct physical properties (e.g., Campbell and Turner, 1985, 1986; Van der Laan and Wyllie, 1993). 
Perfect mixing may be identified by linear mixing trends for all elements, but linear trends may also result from other magmatic processes (Wall et al., 1987). In general, the compositions of end-member magmas are not accurately known, because magmas involved in mixing may have been different from those exposed, both of them may have changed during mixing and they may not have been homogeneous. The hybrid magmas formed by mixing may have been changed by another mechanism like fractional crystallization.

In the Borborema province, northeastern Brazil, hybrid plutonic rocks have been studied, e.g., at Monte das Gameleiras and D. Inês pluton (McMurry et al., 1987a,b) Fazenda Nova/Serra da Japeganga complex (Neves and Vauchez, 1995), Umarizal-Caraúbas complex (Galindo et al., 1995), Itaporonga batholith (Mariano et al., 1996), Bom Jardim, Toritama and Itapetim complexes (Guimarães and Silva Filho, 1998, 2000) and Serra Negra do Norte pluton (Campos et al., 2000).

In this paper, the geochemistry of shoshonitic plutonic rocks and their minerals from the Rio Espinharas pluton, northeastern Brazil, showing field evidence of mingling and mixing of mafic and felsic magmas, are presented. Major and trace elements, rare-earth elements, $\mathrm{Rb}-\mathrm{Sr}$ dating and $\mathrm{Sr}$ isotopic ratios are reported. Modelling of hybridization is presented for major and trace elements.

\section{Geology}

The Seridó Belt of Borborema Province in northeastern Brazil (Fig. 1a) consists mainly of early Proterozoic medium- to high-grade migmatite gneiss (Almeida et al., 1981), which was strongly deformed during the late Proterozoic Brasiliano-Pan-African cycle. Many granitic plutons of Brasiliano age are associated with deep megashear zones (Fig. 1b) (e.g., Galindo et al., 1991; Neves and Vauchez, 1995; Ferreira et al., 1998; Campos et al., 2000). The Rio Espinharas pluton crops out in low-strain zones between two oblique NNE strike-slip megafaults (Figs. 1b, 2). It is exposed over an area of about $260 \mathrm{~km}^{2}$ and does not show evidences of ductile deformation.

This pluton consists mainly of syenogranite and quartz-monzonites (Fig. 2); however, subordinated amounts of diorite, quartz-monzodiorite and quartzsyenite also occur but cannot be represented at the scale of Fig. 2. They intruded a biotite-amphibole augen gneiss of amphibolite facies from the Caicó complex (Gonzalez, 1984). The contact between the pluton and the country rocks is sharp, discordant and faulted with no distinguishable contact metamorphism.

The fine- to medium-grained syenogranite crops out mainly in the S and SSE (Fig. 2), but a small outcrop was found in the NNE. It is $601 \pm 29$ Ma old

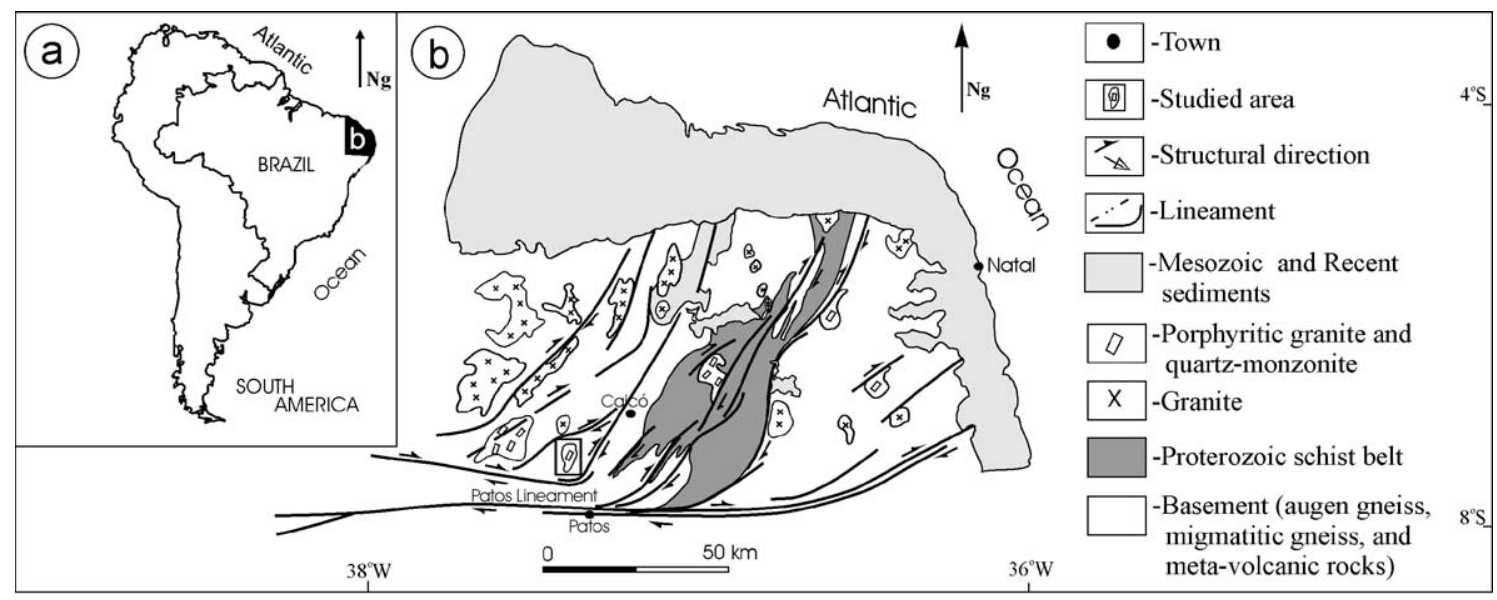

Fig. 1. (a) Location of the Borborema Province and Seridó region in northeastern Brazil. (b) Simplified geological map of this area. 


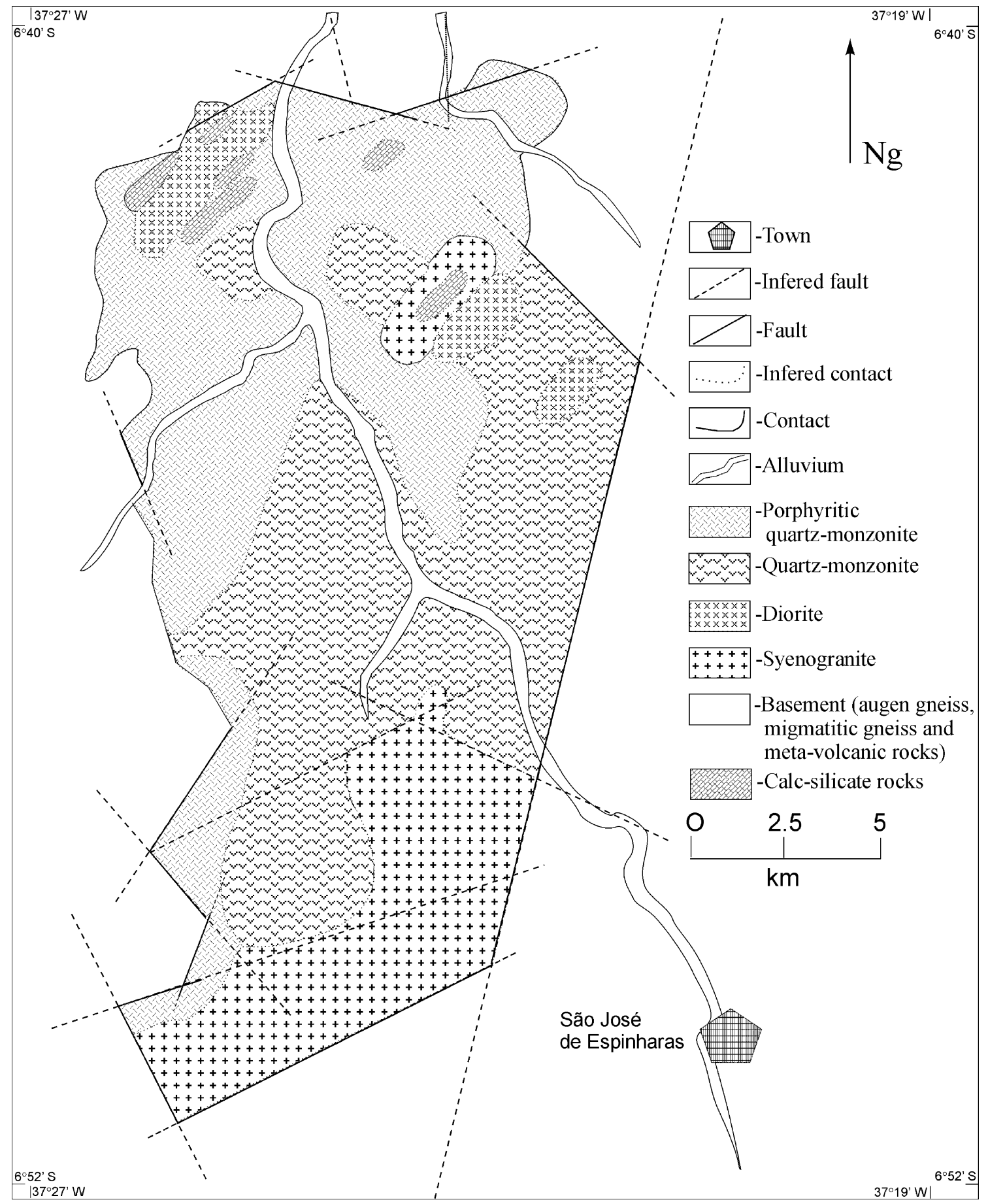

Fig. 2. Geological map of Rio Espinharas pluton. 
given by whole-rock $\mathrm{Rb}-\mathrm{Sr}$ errorchron (Campos, 1997). The fine-grained diorite crops out in the NE and NNW. Locally, the diorite has pillow shapes (Fig. $3 a)$, with finer-grained and more mafic margins than the cores, suggesting the occurrence of chilled margins in contact with host syenogranite. Sharp and also crenulate-to-cuspate contacts between syenogranite and diorite were found (Fig. 3a, b).

The medium- to fine-grained quartz-monzonite crops out mainly in the central part and eastern and northern borders of the pluton. The contact between quartz-monzonite and syenogranite is commonly gradational, rarely sharp and locally grades through a fine- to medium-grained quartz-syenite, which contains some dioritic enclaves and marble xenoliths. Locally, syenogranite is present as masses in the quartz-monzonite and the contacts are gradational. Masses of diorite occur within quartz-monzonite, but between them a heterogeneous rock is present, consisting of hybrid mafic rock with enclaves and showing sharp contacts.
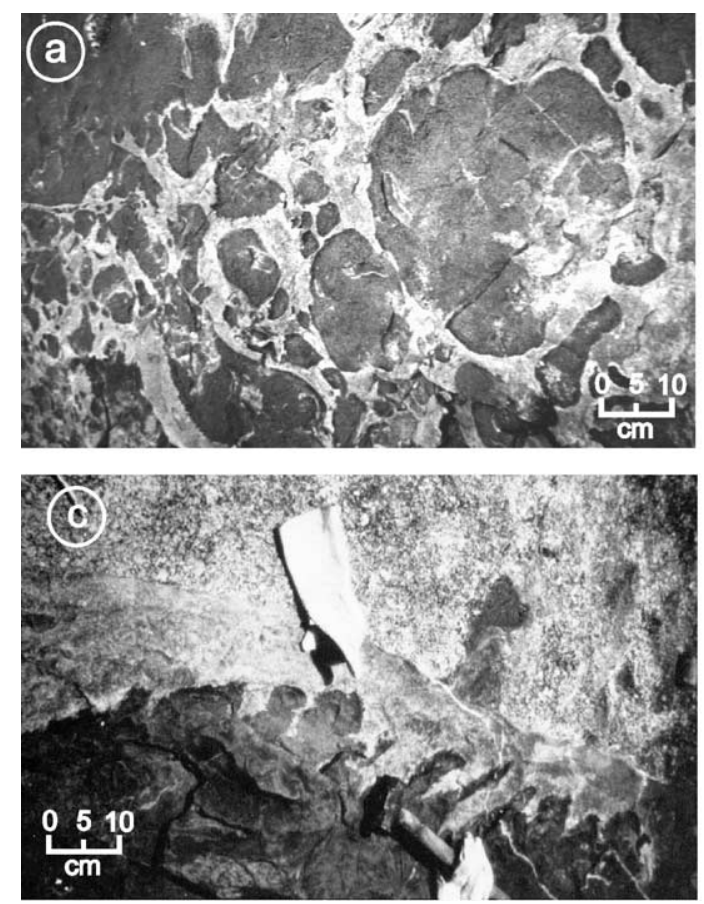

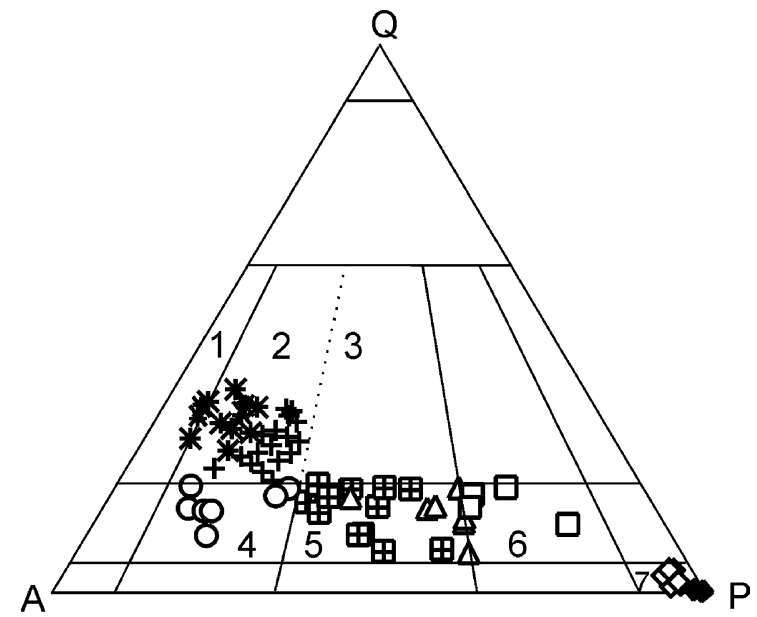

+ - Syenogranite $\diamond$ - Diorite

- Dioritic enclave

$\triangle$ - Quartz-monzonite

$\boxplus$ - Porphyritic quartz-monzonite $\square$ - Quartz-monzodiorite $\bigcirc$ - Quartz-syenite *-Microsyenogranite

Fig. 4. Plot of plutonic rocks from Rio Espinharas on the diagram of Le Bas and Streckeisen (1991). Fields: 1-alkali granite; 2-syenogranite; 3-monzogranite; 4 -quartz-syenite; 5-quartz-monzonite; 6-quartz-monzodiorite; 7-diorite.
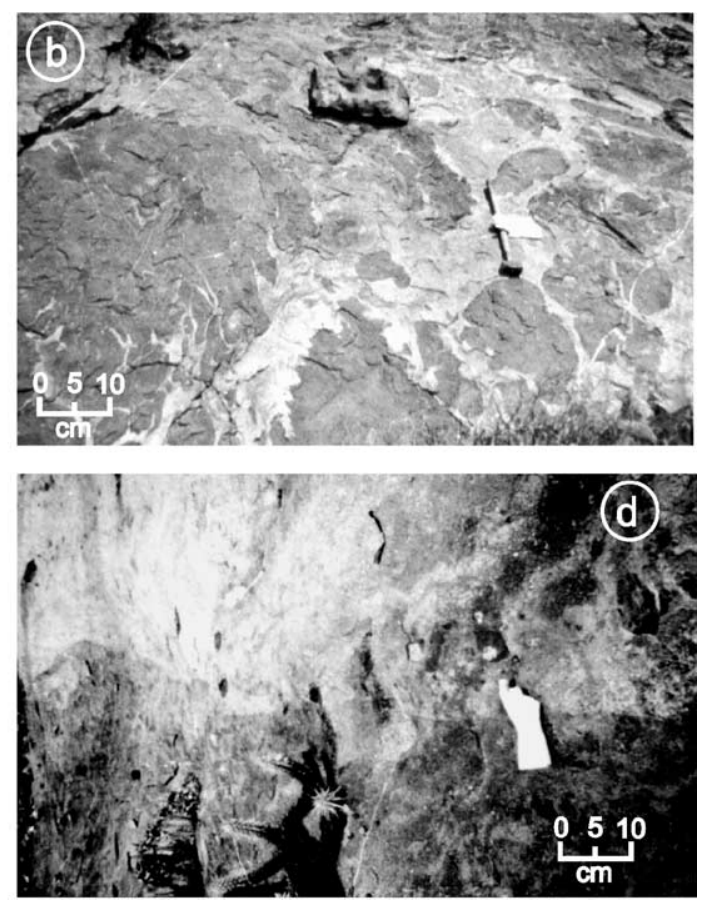

Fig. 3. (a) Diorite pillow shapes showing sharp contacts with syenogranite. (b) Crenulate-to-cuspate contacts between syenogranite and diorite. (c) Crenulate-to-cuspate contact between hybrid porphyritic quartz-monzonite and diorite. (d) Microcline megacrystals of host-rock enclosed in dioritic enclave. Hammer of $100 \mathrm{~cm}$ long and gloves are $20 \mathrm{~cm}$ long. 
Table 1

Modal contents in percent of amphibole and biotite, average chemical analyses in wt.\%, trace and rare-earth elements in ppm of plutonic rocks from the Rio Espinharas pluton, northeastern Brazil

\begin{tabular}{|c|c|c|c|c|c|c|c|c|c|c|c|c|c|c|c|c|}
\hline & \multicolumn{3}{|c|}{ Syenogranite } & \multicolumn{3}{|l|}{ Diorite } & \multirow{2}{*}{$\begin{array}{l}\text { Dioritic } \\
\text { enclaves }\end{array}$} & \multirow{2}{*}{\multicolumn{2}{|c|}{ Quartz-monzonite }} & \multirow{2}{*}{\multicolumn{2}{|c|}{$\begin{array}{l}\text { Porphyritic } \\
\text { quartz-monzonite }\end{array}$}} & \multirow{2}{*}{$\begin{array}{l}\text { Quartz- } \\
\text { monzodiorite }\end{array}$} & \multirow{2}{*}{\multicolumn{2}{|c|}{ Quartz-syenite }} & \multicolumn{2}{|c|}{ Microsyenogranite } \\
\hline & Unc. & C. & & Unc. & C. & & & & & & & & & & & \\
\hline Amphibole & 0.6 & $0.9-20.5$ & & 19.7 & $18.7-23.3$ & & $50.8-65.1$ & $8.8-18.2$ & & $4.2-22.6$ & & $11.4-19.2$ & $14.9-22.9$ & & $0.1-1.3$ & \\
\hline Biotite & 2.5 & $2.0-22.1$ & & 22.0 & $19.3-23.6$ & & $0-13.7$ & $12.4-16.7$ & & $5.6-23.3$ & & $10.9-15.5$ & $7.5-13.7$ & & $0.1-0.8$ & \\
\hline$n$ & 2 & 13 & $\sigma$ & 2 & 8 & $\sigma$ & 2 & 7 & $\sigma$ & 15 & $\sigma$ & 4 & 7 & $\sigma$ & 12 & $\sigma$ \\
\hline $\mathrm{SiO}_{2}$ & 73.07 & 67.97 & 3.40 & 50.45 & 52.21 & 0.40 & 48.63 & 57.38 & 2.65 & 58.91 & 4.13 & 58.15 & 59.50 & 1.83 & 74.79 & 1.49 \\
\hline $\mathrm{TiO}_{2}$ & 0.19 & 0.40 & 0.18 & 2.09 & 2.07 & 0.06 & 0.92 & 1.27 & 0.34 & 1.05 & 0.40 & 1.09 & 0.76 & 0.10 & 0.08 & 0.05 \\
\hline $\mathrm{Al}_{2} \mathrm{O}_{3}$ & 14.34 & 15.22 & 0.74 & 14.95 & 15.00 & 0.24 & 14.63 & 15.57 & 1.12 & 15.29 & 1.15 & 15.34 & 13.31 & 0.48 & 14.00 & 0.72 \\
\hline $\mathrm{Fe}_{2} \mathrm{O}_{3}$ & 0.32 & 1.37 & 0.76 & 4.77 & 4.17 & 0.77 & 3.90 & 3.22 & 0.58 & 2.52 & 0.91 & 3.23 & 2.32 & 0.32 & 0.27 & 0.14 \\
\hline $\mathrm{FeO}$ & 0.84 & 1.19 & 0.85 & 6.66 & 7.17 & 0.77 & 6.79 & 4.26 & 0.96 & 3.71 & 1.06 & 3.86 & 3.43 & 0.42 & 0.46 & 0.12 \\
\hline $\mathrm{MnO}$ & 0.09 & 0.11 & 0.02 & 0.19 & 0.18 & 0.03 & 0.19 & 0.16 & 0.01 & 0.16 & 0.01 & 0.16 & 0.15 & 0.01 & 0.09 & 0.01 \\
\hline $\mathrm{MgO}$ & 0.54 & 1.23 & 1.11 & 6.21 & 4.84 & 0.40 & 8.71 & 3.74 & 0.69 & 4.33 & 0.93 & 4.25 & 5.65 & 0.95 & 0.21 & 0.10 \\
\hline $\mathrm{CaO}$ & 1.07 & 2.09 & 1.05 & 6.89 & 6.39 & 0.50 & 10.38 & 4.88 & 0.55 & 4.81 & 1.22 & 5.24 & 4.59 & 0.46 & 1.02 & 0.33 \\
\hline $\mathrm{Na}_{2} \mathrm{O}$ & 3.99 & 3.92 & 0.27 & 3.29 & 3.46 & 0.13 & 3.34 & 3.38 & 0.32 & 3.42 & 0.22 & 3.35 & 3.05 & 0.12 & 3.80 & 0.29 \\
\hline $\mathrm{K}_{2} \mathrm{O}$ & 4.89 & 5.07 & 0.55 & 2.57 & 2.57 & 0.34 & 1.13 & 4.48 & 0.47 & 4.41 & 0.87 & 3.97 & 5.37 & 0.20 & 4.88 & 0.60 \\
\hline $\mathrm{P}_{2} \mathrm{O}_{5}$ & 0.06 & 0.24 & 0.26 & 0.58 & 0.59 & 0.07 & 0.23 & 0.51 & 0.08 & 0.46 & 0.12 & 0.47 & 0.73 & 0.07 & 0.03 & 0.01 \\
\hline s & $*$ & $*$ & & 0.20 & 0.01 & 0.01 & * & 0.11 & 0.11 & $*$ & 0.29 & 0.01 & $*$ & & $*$ & \\
\hline L.O. & 0.60 & 0.99 & 0.16 & 1.36 & 1.39 & 0.36 & 1.18 & 1.08 & 0.19 & 0.87 & & 0.73 & 1.02 & 0.20 & 0.43 & 0.13 \\
\hline Total & 100.00 & 99.80 & & 100.21 & 100.05 & & 100.03 & 100.04 & & 99.94 & & 99.85 & 99.88 & & 100.06 & \\
\hline $\mathrm{Cl}$ & 86 & 85 & 37 & 120 & 130 & 35 & 43 & 129 & 33 & 116 & 40 & 105 & 109 & 32 & 73 & 30 \\
\hline F & 478 & 1073 & & 772 & 735 & & 1012 & 1204 & & 1303 & & 1028 & 1191 & & 90 & 3 \\
\hline $\mathrm{Cr}$ & * & 59 & 72 & 16 & 12 & 4 & 171 & 52 & 60 & 125 & 58 & 73 & 171 & 84 & 11 & 4 \\
\hline V & 20 & 53 & 32 & 241 & 226 & 11 & 234 & 146 & 37 & 133 & 39 & 148 & 119 & 16 & 11 & 3 \\
\hline $\mathrm{Nb}$ & 12 & 14 & 8 & 37 & 39 & 3 & 13 & 31 & 16 & 19 & 7 & 21 & 10 & 1 & 31 & 41 \\
\hline $\mathrm{Zn}$ & 36 & 50 & 19 & 102 & 122 & 5 & 98 & 94 & 9 & 73 & 14 & 80 & 81 & 10 & 14 & 9 \\
\hline $\mathrm{Li}$ & 12 & 14 & & 13 & 6 & & 5 & 14 & & 11 & & 15 & 10 & & 5 & \\
\hline $\mathrm{Ni}$ & $*$ & 51 & 1 & $*$ & * & 2 & 11 & 38 & & 11 & 2 & 31 & 78 & 39 & $*$ & \\
\hline $\mathrm{Zr}$ & 174 & 286 & 80 & 314 & 352 & 18 & 285 & 526 & 163 & 547 & 242 & 290 & 353 & 116 & 108 & 30 \\
\hline $\mathrm{Cu}$ & $*$ & 56 & 30 & 12 & 16 & 5 & 84 & 8 & 3 & 44 & 29 & 42 & * & & $*$ & \\
\hline $\mathrm{Sc}$ & $*$ & 6 & 5 & 17 & 12 & 6 & 40 & 16 & 5 & 14 & 3 & 15 & 14 & 3 & 6 & 1 \\
\hline Y & 34 & 34 & 4 & 43 & 44 & 4 & 43 & 50 & 10 & 44 & 5 & 51 & 45 & 5 & 40 & 13 \\
\hline $\mathrm{Sr}$ & 260 & 660 & 383 & 629 & 712 & 80 & 420 & 750 & 274 & 944 & 192 & 802 & 1347 & 112 & 184 & 104 \\
\hline $\mathrm{Ba}$ & 738 & 1833 & 901 & 1069 & 1150 & 204 & 289 & 2236 & 555 & 2829 & 715 & 1906 & 3279 & 397 & 377 & 310 \\
\hline $\mathrm{Rb}$ & 234 & 174 & 41 & 85 & 76 & 12 & 57 & 133 & 13 & 124 & 19 & 124 & 132 & 13 & 220 & 80 \\
\hline $\mathrm{La}$ & 36 & 61 & & 45 & 50 & & 18 & 74 & & 86 & & 61 & 50 & & 43 & \\
\hline $\mathrm{Ce}$ & 43 & 96 & & 86 & 90 & & 36 & 105 & & 133 & & 105 & 88 & & 74 & \\
\hline $\mathrm{Nd}$ & 16 & 43 & & 49 & 50 & & 26 & 51 & & 55 & & 49 & 49 & & 31 & \\
\hline $\mathrm{Sm}$ & 2.00 & 5 & & 8 & 8 & & 5 & 9 & & 8 & & 8 & 8 & & 3 & \\
\hline $\mathrm{Eu}$ & 1.00 & 2.00 & & 2.00 & 2.00 & & 1.00 & 2.00 & & 2.33 & & 2.00 & 2.00 & & 1.00 & \\
\hline $\mathrm{Gd}$ & 2.00 & 4 & & 6 & 6 & & 4 & 6 & & 6 & & 4.5 & 6 & & 3 & \\
\hline $\mathrm{Tb}$ & 0.31 & 0.57 & & 0.99 & 0.91 & & 0.68 & 0.78 & & 0.78 & & 0.93 & 0.75 & & 0.55 & \\
\hline $\mathrm{Tm}$ & 0.25 & 0.23 & & 0.37 & 0.33 & & 0.40 & 0.34 & & 0.37 & & 0.49 & 0.33 & & 0.42 & \\
\hline $\mathrm{Yb}$ & 1.00 & 1.00 & & 2.00 & 2.00 & & 2.00 & 2.33 & & 2.33 & & 2.00 & 2.00 & & 0.33 & \\
\hline $\mathrm{Lu}$ & 0.13 & 0.17 & & 0.28 & 0.17 & & 0.34 & 0.27 & & 0.29 & & 0.29 & 0.24 & & 0.25 & \\
\hline
\end{tabular}

Unc.: uncontaminated; c.: contaminated; $n$ : number of analyzed samples; $\sigma$ : standard deviation; L.O.: Loss on ignition; *: below the limit of sensitivity. F, Li and rare-earth elements were only determined in two or three samples of each rock type. Analyst: T.F.C. Campos. 
In the southern and central parts of the pluton, small masses of medium- to fine-grained quartzmonzodiorite are present in the quartz-monzonite and, generally, the contacts are gradational. Rarely, there are also large monzodioritic blocks of elliptical shape showing sharp contacts with the quartz-monzonite.

The medium- to coarse-grained porphyritic quartzmonzonite crops out in the N, NNW and in the western border of the pluton. Its contact with the syenogranite is sharp, whereas that with diorite is gradational. Lobate and cuspate contacts were found (Fig. 3c). Heterogeneous hybrid rock is commonly present between diorite and quartz-monzonite (Fig. 3d). The contact between quartz-monzonite and porphyritic quartz-monzonite is gradational. Dioritic dykes cut the porphyritic quartz-monzonite and at their contacts, the diorite is finer-grained and richer in mafic minerals than inside the dykes. A dyke resulting from disruption of diorite due to intrusion of porphyritic quartz-monzonite is locally observed. All the plutonic rocks are cut by veins and dikes of biotite microsyenogranite of $589 \pm 23 \mathrm{Ma}$ (Campos, 1997), which locally passes to pegmatite.

The syenogranite, quartz-monzonite, porphyritic quartz-monzonite and quartz-syenite contain microgranular enclaves of rounded and ovoid shapes, which are locally oriented by the magmatic flow of
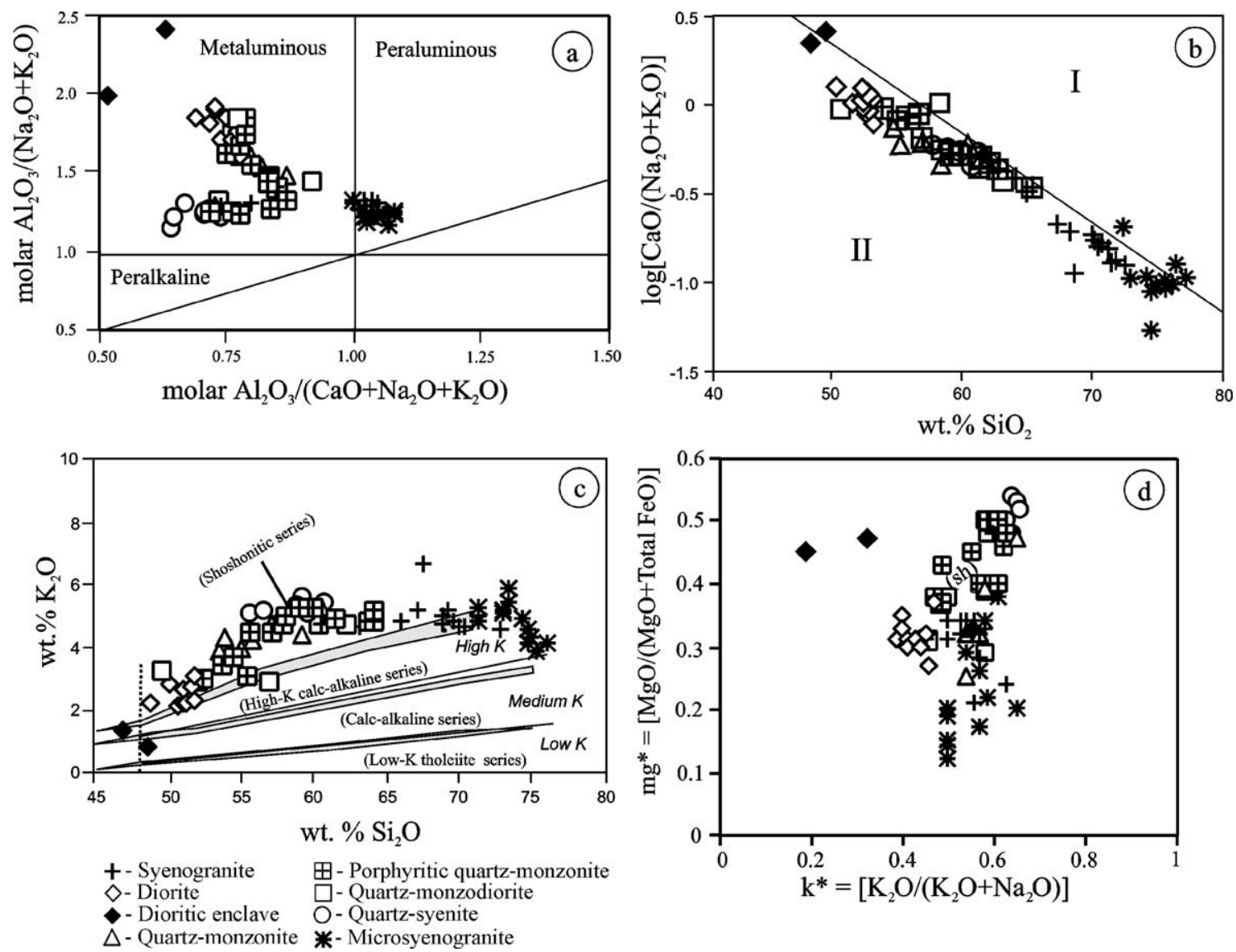

Fig. 5. Plot of plutonic rocks from Rio Espinharas on: (a) $\mathrm{Al}_{2} \mathrm{O}_{3} /\left(\mathrm{Na}_{2} \mathrm{O}+\mathrm{K}_{2} \mathrm{O}\right)$ vs. $\mathrm{Al}_{2} \mathrm{O}_{3} /\left(\mathrm{CaO}+\mathrm{Na}_{2} \mathrm{O}+\mathrm{K}_{2} \mathrm{O}\right)$ diagram of Maniar and Piccoli (1989); (b) Peacock index $\mathrm{CaO} /\left(\mathrm{Na}_{2} \mathrm{O}+\mathrm{K}_{2} \mathrm{O}\right)$ vs. $\mathrm{SiO}_{2}$ after Brown (1981) with fields: I-calc-alkaline and II-alkali-calcic; (c) $\mathrm{K}_{2} \mathrm{O}$ vs. $\mathrm{SiO} \mathrm{O}_{2}$ diagram with information from Peccerillo and Taylor (1976), Ewart (1982), Innocenti et al. (1982) and Rickwood (1989); (d) mg* vs. $k^{*}$ diagram (Sabatier, 1991), sh—shoshonite. 
host-rocks, particularly in the porphyritic quartzmonzonite. Locally, large composite enclaves occur in the syenogranite, and very small enclaves and clots are found in the porphyritic quartz-monzonite. The rounded enclaves are $3-40 \mathrm{~cm}$ in diameter and the ovoid enclaves range from $0.5 \times 2$ to $20 \times 100$ $\mathrm{cm}$. The contacts of enclaves with the host-rock are sharp to gradational. The sharp contacts are commonly found among the smallest enclaves showing a finer-grained and more mafic margin than the core. Crenulate and lobate-to-cuspate contacts were found. The enclaves are finer-grained and darker than the host-rock and partially enclose phenocrysts of hostrock (Fig. 3d). Commonly, the enclaves have a
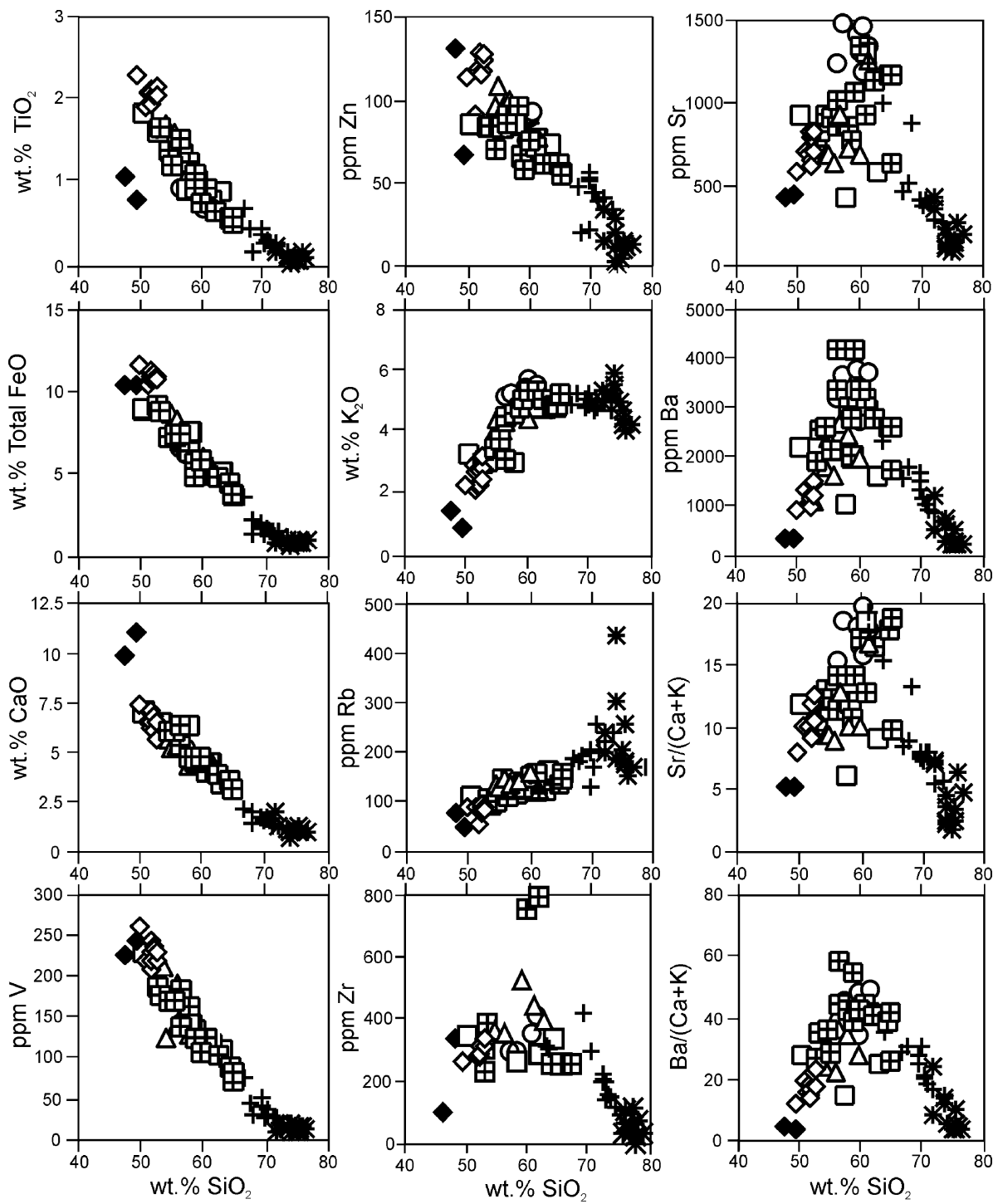

+ - Syenogranite

$\diamond$-Diorite

$\boxplus$ - Porphyritic quartz-monzonite

- Dioritic enclave

$\square$ - Quartz-monzodiorite

$\triangle$ - Quartz-monzonite

O-Quartz-syenite

*- Microsyenogranite

Fig. 6. Variation diagrams of selected major and trace elements and ratios of plutonic rocks from Rio Espinharas. 
dioritic composition. Calc-silicate xenoliths occur in the syenogranite, diorite and porphyritic quartzmonzonite.

\section{Analytical methods}

Major and trace elements of rocks were determined by X-ray fluorescence (XRF) at the Department of Earth Sciences, University of Manchester, UK, using the method of Brown et al. (1973). A precision of $\pm 1 \%$ was obtained for major elements and $\mathrm{Rb}$, and of $\pm 4 \%$ for other trace elements. Sn was not detected. Loss on ignition for rocks was determined at the Institute of Geosciences, Federal University of Rio Grande do Sul, Brazil. The chemical analyses of minerals were determined with a modified Cambridge Geoscan energy-dispersive system at Manchester University with a precision of $\pm 5 \%$.

Biotite was separated with magnetic separator and heavy liquids. The purity was estimated $\sim 99.8 \%$ by petrographic examination. The main contaminant is apatite, but zircon inclusions in biotite were also found. The trace element contents of biotite were determined by XRF as for the rocks.

$\mathrm{FeO}, \mathrm{Li}$ and $\mathrm{F}$ of rocks and biotite were determined at the Department of Earth Sciences, Coimbra University, Portugal. $\mathrm{FeO}$ was determined by titration with standardized potassium permanganate solution, with a precision of $\pm 1 \%$. Li was determined by atomic absorption and $\mathrm{F}$ by selective ion electrode analysis, and both with a precision of $\pm 2 \%$. Rare-earth elements of rocks were determined by neutron activation analysis with a precision of $\pm 5 \%$ at Imperial College Reactor Centre, Ascot, UK.

$\mathrm{Rb}-\mathrm{Sr}$ isotopic data were obtained at the Department of Earth Sciences, Oxford University, UK. The techniques used are those described by Whitehouse (1990). $\mathrm{Rb} / \mathrm{Sr}$ ratios were determined by XRF with a precision of $\pm 1 \%$. Sr isotopes were measured on a VG-Micromass 30 Spectrometer, $2 \sigma$ errors in ${ }^{87} \mathrm{Sr} /{ }^{86} \mathrm{Sr}$ ratios are smaller than $0.01 \%$.

\section{Petrography}

The plutonic rocks from Rio Espinharas are classified modally (Fig. 4) and most of them have hypidiomorphic granular texture. However, diorite and diorite enclaves show doleritic texture. The porphyritic quartz-monzonite has feldspar megacrysts, whose average dimensions are $3 \times 2 \mathrm{~cm}$, but may reach $9 \times 4 \mathrm{~cm}$.

The plutonic rocks contain quartz, plagioclase, microcline, clinopyroxene, amphibole, biotite, titanite, allanite, epidote, apatite, zircon and magnetite. Garnet is locally present in biotite microsyenogranite veins and dikes and ilmenite occurs in the porphyritic quartz-monzonite.

The dioritic enclaves have higher contents of ferromagnesian minerals (amphibole + biotite) than host quartz-monzonite (Table 1).

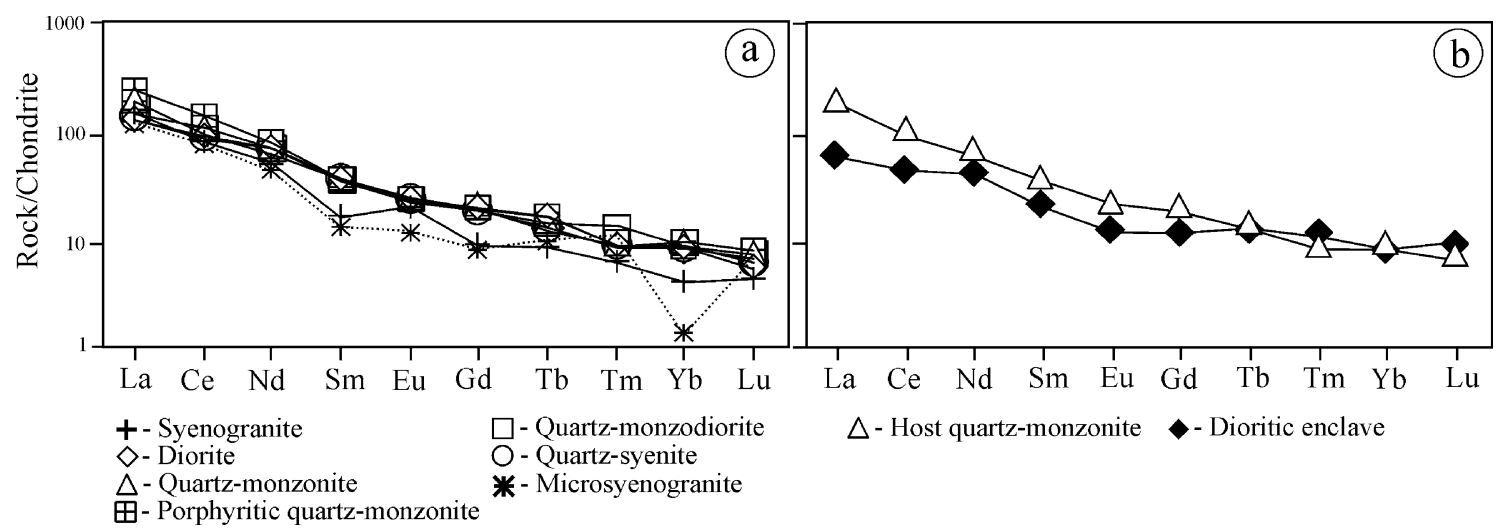

Fig. 7. Average chondrite-normalized REE abundances of: (a) plutonic rocks from Rio Espinharas. Microsyenogranite has a negative Yb anomaly attributed to a low $\mathrm{Yb}$ content close to the detection limit; (b) dioritic enclaves and host quartz-monzonite. 
Quartz crystals are anhedral, display undulatory extinction and contain inclusions of zircon, apatite, amphibole and biotite. Rare globular quartz is found. Plagioclase and microperthitic microcline are subhedral to anhedral. Phenocrysts, matrix and xenocrysts were distinguished texturally in both feldspars. Phenocrysts contain a few inclusions of biotite, zircon and apatite. Xenocrysts show poikilitic texture with abundant inclusions of amphibole, biotite, quartz, zircon and apatite. K-feldspar xenocrysts also present inclusions of plagioclase. In the porphyritic quartz-monzonite, phenocrysts and xenocrysts have similar average dimensions of $30 \times 20$ $\mathrm{mm}$ for microcline and $25 \times 15 \mathrm{~mm}$ for plagioclase, but microxenocrysts tend to be slightly bigger than microphenocrysts in the other rock types. Plagioclase is polysynthetically twinned and complexely zoned. Myrmekite is locally found. Microcline is cross-hatched twinned and locally twinned on the Carlsbad law.

Augite crystals with calculated $\mathrm{Fe}^{3+}$ (Droop, 1987) and $\mathrm{Mg}^{*}=\left[100 \mathrm{Mg} /\left(\mathrm{Mg}+\mathrm{Fe}^{2+}+\mathrm{Fe}^{3+}+\mathrm{Mn}\right)\right]$ of 73 and $72-76$ are found in diorite and dioritic enclaves, respectively, whereas diopside (Morimoto et al., 1989) with $\mathrm{Mg}^{*}$ of $71-73,59-64$ and 67-73 occurs in quartz-monzonite, porphyritic quartzmonzonite and quartz-syenite, respectively. However, single-zoned crystals with a core of augite and a rim of diopside are found in the quartz-syenite. $\mathrm{Mg}^{*}$ has similar value in core and rim of singlezoned crystals, with a minimum of 71 and a maximum of 76 found in distinct crystals. Clinopyroxene is rarely euhedral, but commonly subhedral, slightly pleochroic, from pale green to yellowish green. In general, clinopyroxene crystals are rimmed by amphibole.

Amphibole is subhedral and pleochroic, commonly from dark green to brown and more rarely from light green to colourless. The modal abundance is given in Table 1. Crystals are scattered throughout the rocks, but they also occur forming clots. Commonly, they show patch-type extinction, corroded borders and poikilitic texture with abundant inclusions of zircon, apatite, magnetite, quartz, plagioclase and rare titanite. Skeletal forms are also found in other crystals.

Biotite is subhedral and pleochroic from greenish brown to yellow. The modal content is presented in Table 1. It is scattered throughout the rocks, but also occurs forming clots. It is commonly intergrown with amphibole, but locally replaces it. Biotite contains inclusions of zircon, magnetite, apatite and rarely quartz.

Titanite is either subhedral to anhedral, pleochroic from brownish yellow to pale yellow, and contains

Table 2

$\mathrm{Rb}-\mathrm{Sr}$ isotopic analyses of plutonic rocks from the Rio Espinharas pluton, northeastern Brazil

\begin{tabular}{|c|c|c|c|c|c|c|}
\hline Samples & $\begin{array}{l}\mathrm{Rb} \\
(\mathrm{ppm})\end{array}$ & $\begin{array}{l}\mathrm{Sr} \\
(\mathrm{ppm})\end{array}$ & ${ }^{87} \mathrm{Rb} /{ }^{86} \mathrm{Sr}$ & ${ }^{87} \mathrm{Sr} /{ }^{86} \mathrm{Sr}$ & \pm Error & $\begin{array}{l}\left({ }^{87} \mathrm{Sr} /\right. \\
\left.{ }^{86} \mathrm{Sr}\right)_{0}\end{array}$ \\
\hline \multicolumn{7}{|c|}{ Syenogranite } \\
\hline 38 & 128.0 & 991.1 & 0.374 & 0.71166 & 0.00002 & 0.7085 \\
\hline 42 & 252.8 & 298.8 & 2.453 & 0.72907 & 0.00002 & 0.7080 \\
\hline 43 & 201.7 & 393.8 & 1.484 & 0.72022 & 0.00002 & 0.7075 \\
\hline 44 & 201.0 & 288.5 & 2.019 & 0.72568 & 0.00002 & 0.7084 \\
\hline 45 & 119.8 & 1360.0 & 0.255 & 0.71031 & 0.00002 & 0.7081 \\
\hline 71 & 175.8 & 500.0 & 1.018 & 0.71756 & 0.00002 & 0.7088 \\
\hline 32 & 220.7 & 268.5 & 2.382 & 0.72879 & 0.00004 & 0.7084 \\
\hline 37 & 245.6 & 252.1 & 2.826 & 0.73278 & 0.00004 & 0.7086 \\
\hline
\end{tabular}

$\begin{array}{lllllll}\text { Diorite } & & & & & & \\ 116 & 49.1 & 666.4 & 0.213 & 0.70826 & 0.00002 & 0.7064 \\ 21 & 78.7 & 598.9 & 0.380 & 0.70965 & 0.00002 & 0.7064\end{array}$

Quartz-monzonite

$\begin{array}{rrrrrrr}55 & 116.2 & 684.4 & 0.492 & 0.71341 & 0.00002 & 0.7092 \\ 54 & 131.0 & 926.3 & 0.409 & 0.71296 & 0.00002 & 0.7095 \\ 62 & 121.1 & 1256.6 & 0.279 & 0.71068 & 0.00002 & 0.7083\end{array}$

P. quartz-monzonite

$\begin{array}{lrrrrrr}11 & 129.8 & 848.7 & 0.443 & 0.71200 & 0.00002 & 0.7082 \\ 2 & 118.4 & 1096.2 & 0.313 & 0.71052 & 0.00003 & 0.7078 \\ 13 & 139.7 & 624.5 & 0.647 & 0.71356 & 0.00002 & 0.7080\end{array}$

Quartz-monzodiorite

$\begin{array}{lllllll}57 & 161.3 & 565.8 & 0.825 & 0.71569 & 0.00002 & 0.7086\end{array}$

Quartz-syenite

$\begin{array}{lllllll}61 & 135.7 & 1417.3 & 0.277 & 0.71005 & 0.00002 & 0.7077\end{array}$

Microsyenogranite

$\begin{array}{lrrrrrr}26 & 434.0 & 94.5 & 13.443 & 0.82283 & 0.00002 & 0.7099 \\ 28 & 166.6 & 183.7 & 2.630 & 0.73380 & 0.00002 & 0.7117 \\ 33 & 250.7 & 138.3 & 5.267 & 0.75397 & 0.00001 & 0.7097 \\ 34 & 299.4 & 116.9 & 7.457 & 0.77402 & 0.00002 & 0.7114 \\ 35 & 196.6 & 413.0 & 1.379 & 0.72128 & 0.00002 & 0.7097 \\ 118 & 175.1 & 123.0 & 4.134 & 0.74401 & 0.00002 & 0.7093 \\ 30 & 180.4 & 175.5 & 2.983 & 0.73567 & 0.00003 & 0.7106\end{array}$

P.- porphyritic. $\left({ }^{87} \mathrm{Sr} /{ }^{86} \mathrm{Sr}\right)_{0}$ ratios were calculated for the age of 601 Ma for syenogranite, diorite, quartz-monzonite, porphyritic quartz-monzonite, quartz-monzodiorite and quartz-syenite and $589 \mathrm{Ma}$ for microsyenogranite. 
inclusions of apatite and rarely magnetite. Allanite is euhedral to subhedral, slightly pleochroic, with metamictic core. Epidote is euhedral to subhedral, pleochroic from greenish yellow to yellowish green, found scattered throughout the rocks or associated with mafic minerals, particularly amphiboles, but does not rim them. Some crystals have a core of allanite and a rim of euhedral epidote. Therefore, these features are consistent with those of magmatic epidote (Zen and Hammarstrom, 1984; Keane and Morrison, 1997). Euhedral epidote in contact with plagioclase shows corroded margins, which indicates dissolution and reaction with magma before solidification (Brandon at al., 1996). Secondary anhedral epidote formed from alteration of plagioclase is rarely found.

Euhedral zircon occurs mainly as inclusions in several minerals, particularly biotite, amphibole and quartz. Apatite occurs as euhedral inclusions in amphibole, biotite and titanite, and also scattered throughout the rocks. However, diorite and dioritic enclaves contain acicular crystals of apatite in close parallel needles or as radial aggregates of needles enclosed in feldspars, amphibole and more rarely in quartz. Commonly, each acicular crystal is hollow along its length, but it is not always continuous. Magnetite is euhedral to subhedral and occurs commonly as inclusions in amphibole, biotite and titanite. In the porphyritic quartz-monzonite, some single crystals of ilmenite are present, but there are some crystals of magnetite showing ilmenite exsolutions concentrated in the centre of the crystal.

Microsyenogranite contains euhedral garnet of spessartite-almandine composition and contains rare inclusions of quartz.

\section{Whole-rock geochemistry}

\subsection{Major and trace elements and REE}

Average major and trace element contents and REE data of plutonic rocks from the Rio Espinharas pluton are given in Table 1. Most of these rocks are metaluminous; syenogranite ranges from metaluminous to peraluminous with $\mathrm{A} / \mathrm{CNK}=$ molecular $\mathrm{Al}_{2} \mathrm{O}_{3} /(\mathrm{CaO}+$ $\mathrm{Na}_{2} \mathrm{O}+\mathrm{K}_{2} \mathrm{O}$ ) of $0.74-1.05$ and microsyenogranite has A/CNK of 1.00-1.08 (Fig. 5a). Normative corundum is only found in syenogranite and microsyenogranite, with values up to $1.27 \%$ and $2.28 \%$, respectively. Most rock have $\mathrm{K}_{2} \mathrm{O}>\mathrm{Na}_{2} \mathrm{O}$ (Table 1), except diorite and dioritic enclaves. Most are alkali-calcic (Fig. 5b) and plot in the field of the shoshonitic series (Fig. 5c, d), which are scarce (Duchesne et al., 1998), but do not have characteristics of ultrapotassic rocks (Foley et al., 1987). Microsyenogranite plots in the high-K field (Fig. 5c) and, generally, has the lowest $\mathrm{mg}^{*}=\mathrm{MgO} /(\mathrm{MgO}+$ total $\mathrm{FeO})$ values (Fig. 5d). The dioritic enclaves are richer in $\mathrm{FeO}, \mathrm{MgO}, \mathrm{CaO}, \mathrm{V}$ and poorer in $\mathrm{SiO}_{2}, \mathrm{~K}_{2} \mathrm{O}, \mathrm{Rb}, \mathrm{Sr}, \mathrm{Ba}, \mathrm{Sr} /(\mathrm{Ca}+\mathrm{K})$ and $\mathrm{Ba} /$
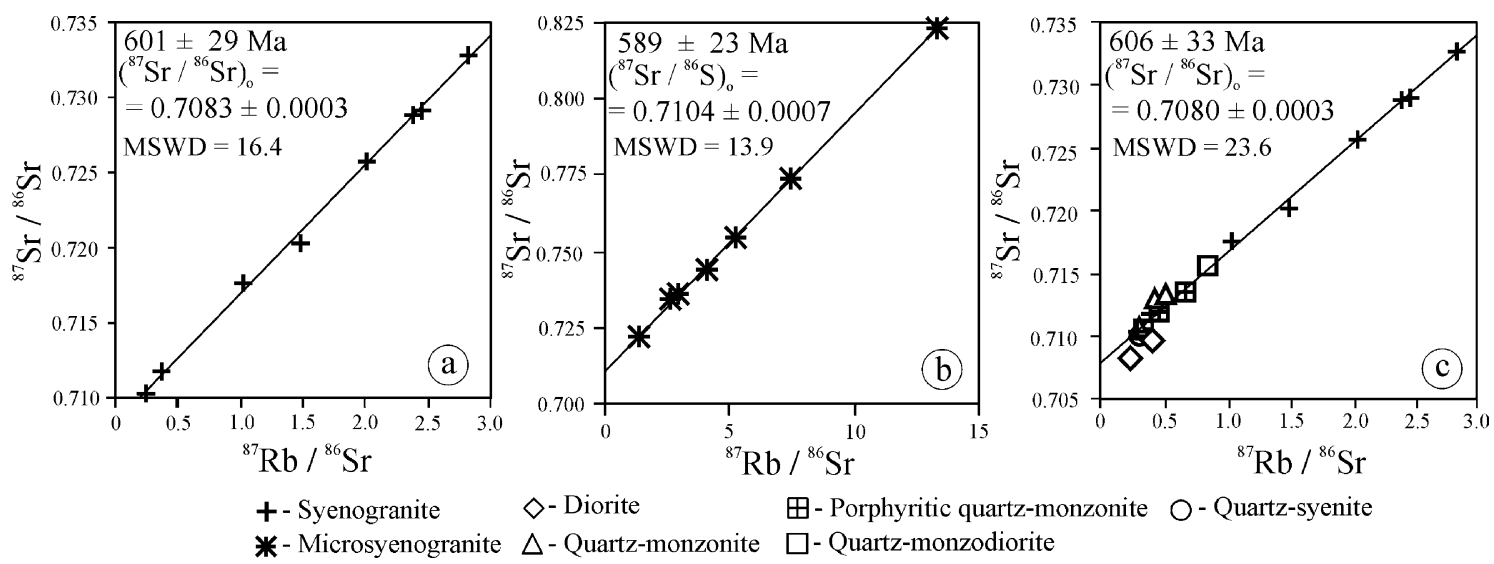

$\diamond$ - Diorite

$\triangle$ - Quartz-monzonite

田-Porphyritic quartz-monzonite $\bigcirc$-Quartz-syenite

$\square$ - Quartz-monzodiorite

Fig. 8. Whole-rock $\mathrm{Rb}-\mathrm{Sr}$ errorchrons of (a) syenogranite; (b) microsyenogranite; (c) syenogranite, diorite, quartz-monzonite, porphyritic quartz-monzonite, quartz-monzodiorite and quartz-syenite. 
$(\mathrm{Ca}+\mathrm{K})$ than the host quartz-monzonite (Fig. 6 and Table 1). Most of the composition trends are linear (Fig. 6), but $\mathrm{K}_{2} \mathrm{O}$ is nonlinear and $\mathrm{Zr}, \mathrm{Sr}, \mathrm{Ba}, \mathrm{Sr} /$ $(\mathrm{Ca}+\mathrm{K})$ and $\mathrm{Ba} /(\mathrm{Ca}+\mathrm{K})$ show bell-shaped data arrays.

REE patterns of plutonic rocks from Rio Espinharas pluton are more enriched in LREE with respect to HREE as shown by $\mathrm{La}_{\mathrm{N}} / \mathrm{Lu}_{\mathrm{N}}=17-33$ and Fig. 7a. Most of the rare-earth patterns overlap, but microsyenogranite is generally the poorest in REE. The dioritic enclaves have lower $\mathrm{La}_{N} / \mathrm{Lu}_{\mathrm{N}}$ ratio of 6 and are poorer in LREE than the host quartz-monzonite (Fig. 7b).

\section{2. $R b-S r$ isotope geochemistry}

$\mathrm{Rb}-\mathrm{Sr}$ isotopic data are given in Table 2. For syenogranite and microsyenogranite, the respective whole-rock $\mathrm{Rb}-\mathrm{Sr}$ errorchron yields $601 \pm 29$ and $589 \pm 23$ Ma with $\left({ }^{87} \mathrm{Sr} /{ }^{86} \mathrm{Sr}\right)_{0}$ ratios of $0.7083 \pm$ 0.0003 and $0.7104 \pm 0.0007$ (Fig. 8a, b), which are within the range of other Brasiliano granites from the Seridó Belt (e.g., McMurry et al., 1987a,b; Galindo et al., 1995; Campos et al., 2000). Syenogranite, quartzmonzonite, porphyritic quartz-monzonite, quartzmonzodiorite, quartz-syenite and diorite define a pseudo-errorchron (Fig. 8c) and yield an age of $606 \pm 33 \mathrm{Ma}$ and $\left({ }^{87} \mathrm{Sr} /{ }^{86} \mathrm{Sr}\right)_{0}$ ratio of $0.7080 \pm$ 0.0003 , although this ratio is similar to that for the syenogranite. Taking into account the uncertainties, the three errorchrons yield identical ages.

\section{Geochemistry of minerals}

\subsection{Feldspars}

Compositions of microcline and plagioclase are given in Table 3. Porphyritic quartz-monzonite has phenocrysts and xenocrysts of both feldspars. Feldspar microphenocrysts and microxenocrysts are found in the other rock types. The microcline microphenocrysts have the highest $\mathrm{Ba}$ contents.

Matrix plagioclase has lower anorthite content than microphenocryst plagioclase. The anorthite content of microxenocryst plagioclase is similar or lower than that of the respective matrix plagioclase. Reverse zonation is found in some plagioclase matrix and microxenocrysts (Table 3). Dioritic enclaves have similar to higher anorthite content $\left(\mathrm{An}_{18}-\mathrm{An}_{54}\right)$ of plagioclase than that of the matrix plagioclase from host quartz-monzonite $\left(\mathrm{An}_{22}-\mathrm{An}_{40}\right)$.

\subsection{Amphibole}

Compositions of amphibole are given in Table 4 and displayed in Fig. 9. Single crystals of magnesiohornblende, ferrohornblende, edenite and hastingsite

Table 3

Compositions of feldspars of plutonic rocks from the Rio Espinharas pluton, northeastern Brazil

\begin{tabular}{|c|c|c|c|c|c|c|c|c|c|}
\hline & & Syenogranite & Diorite & $\begin{array}{l}\text { Dioritic } \\
\text { enclave }\end{array}$ & $\begin{array}{l}\text { Quartz- } \\
\text { monzonite }\end{array}$ & $\begin{array}{l}\text { Porphyritic } \\
\text { quartz- } \\
\text { monzonite }\end{array}$ & $\begin{array}{l}\text { Quartz- } \\
\text { monzodiorite }\end{array}$ & $\begin{array}{l}\text { Quartz- } \\
\text { syenite }\end{array}$ & Microsyenogranite \\
\hline \multirow{3}{*}{$\begin{array}{l}\mathrm{BaO} \text { wt. } \% \\
\text { of } \\
\text { microcline }\end{array}$} & Phenocrysts & $0.40-1.59$ & - & - & - & $1.13-2.75$ & - & - & $0.23-0.95$ \\
\hline & Matrix & $0.16-1.20$ & $0.10-0.99$ & - & $0.59-1.38$ & $0.24-2.42$ & $0.25-1.27$ & $0.21-1.44$ & 0.00 \\
\hline & Xenocrysts & $0.42-1.24$ & - & - & $1.00-1.30$ & $0.71-1.80$ & $1.90-1.32$ & $0.45-1.28$ & $0.00-0.23$ \\
\hline \multirow{3}{*}{$\begin{array}{l}\text { Orthoclase } \\
\text { content of } \\
\text { microcline }\end{array}$} & Phenocrysts & $\mathrm{Or}_{87}-\mathrm{Or}_{92}$ & - & - & - & $\mathrm{Or}_{75}-\mathrm{Or}_{89}$ & - & - & $\mathrm{Or}_{81}-\mathrm{Or}_{90}$ \\
\hline & Matrix & $\mathrm{Or}_{87}-\mathrm{Or}_{94}$ & $\mathrm{Or}_{82}-\mathrm{Or}_{89}$ & - & $\mathrm{Or}_{83}-\mathrm{Or}_{95}$ & $\mathrm{Or}_{78}-\mathrm{Or}_{92}$ & $\mathrm{Or}_{88}-\mathrm{Or}_{94}$ & $\mathrm{Or}_{81}-\mathrm{Or}_{92}$ & $\mathrm{Or}_{83}-\mathrm{Or}_{95}$ \\
\hline & Xenocrysts & $\mathrm{Or}_{88}-\mathrm{Or}_{89}$ & - & - & $\mathrm{Or}_{85}-\mathrm{Or}_{90}$ & $\mathrm{Or}_{80}-\mathrm{Or}_{95}$ & $\mathrm{Or}_{84}-\mathrm{Or}_{90}$ & $\mathrm{Or}_{84}-\mathrm{Or}_{91}$ & $\mathrm{Or}_{85}-\mathrm{Or}_{96}$ \\
\hline \multirow{5}{*}{$\begin{array}{l}\text { Anorthite } \\
\text { content of } \\
\text { plagioclase }\end{array}$} & Phenocrysts & - & - & - & - & $\mathrm{An}_{31}-\mathrm{An}_{43}$ & $\mathrm{An}_{28}-\mathrm{An}_{45}$ & $\mathrm{An}_{16}-\mathrm{An}_{23}$ & - \\
\hline & Matrix (n) & $\mathrm{An}_{2}-\mathrm{An}_{19}$ & $\mathrm{An}_{18}-\mathrm{An}_{52}$ & $\mathrm{An}_{32}-\mathrm{An}_{48}$ & $\mathrm{An}_{22}-\mathrm{An}_{40}$ & $\mathrm{An}_{14}-\mathrm{An}_{37}$ & $\mathrm{An}_{24}-\mathrm{An}_{40}$ & $\mathrm{An}_{10}-\mathrm{An}_{17}$ & $\mathrm{An}_{4}-\mathrm{An}_{17}$ \\
\hline & $(\mathrm{r})$ & $\mathrm{An}_{7}-\mathrm{An}_{17}$ & $\mathrm{An}_{22}-\mathrm{An}_{43}$ & $\mathrm{An}_{32}-\mathrm{An}_{42}$ & $\mathrm{An}_{26}-\mathrm{An}_{32}$ & $\mathrm{An}_{24}-\mathrm{An}_{29}$ & - & $\mathrm{An}_{13}-\mathrm{An}_{15}$ & - \\
\hline & Xenocrysts (n) & - & $\mathrm{An}_{23}-\mathrm{An}_{54}$ & - & $\mathrm{An}_{22}-\mathrm{An}_{31}$ & $\mathrm{An}_{13}-\mathrm{An}_{36}$ & $\mathrm{An}_{24}-\mathrm{An}_{27}$ & $\mathrm{An}_{16}-\mathrm{An}_{19}$ & $\mathrm{An}_{13}-\mathrm{An}_{15}$ \\
\hline & $(\mathrm{r})$ & - & $\mathrm{An}_{23}-\mathrm{An}_{53}$ & - & - & $\mathrm{An}_{25}-\mathrm{An}_{36}$ & $\mathrm{An}_{23}-\mathrm{An}_{27}$ & - & $\mathrm{An}_{6}-\mathrm{An}_{8}$ \\
\hline
\end{tabular}

Commonly the rock types contain microphenocrysts and microxenocrysts, except for the porphyritic quartz-monzonite, which contains phenocrysts and xenocrysts. $\mathrm{n}$-Normal zoned plagioclase; $\mathrm{r}$ - reverse zoned plagioclase. Analyst: T.F.C. Campos. 
Table 4

Selected chemical analyses in wt.\% of amphibole of plutonic rocks from the Rio Espinharas pluton, northeastern Brazil

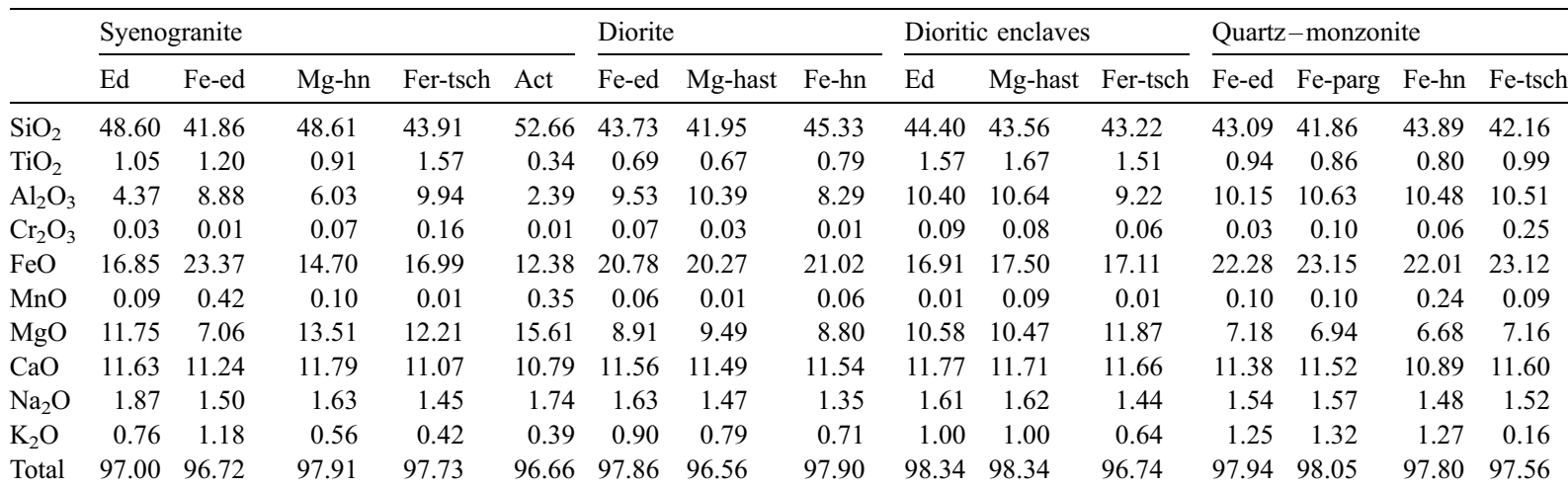

\begin{tabular}{|c|c|c|c|c|c|c|c|c|c|c|c|}
\hline & \multicolumn{5}{|c|}{ Porphyritic quartz-monzonite } & \multicolumn{3}{|c|}{ Quartz-monzodiorite } & \multicolumn{3}{|c|}{ Quartz-syenite } \\
\hline & Fe-ed & Mg-hast & Fe-parg & Fe-hn & Act & Fe-ed & Fe-parg & Mg-hn & Ed & Mg-hn & Act \\
\hline $\mathrm{SiO}_{2}$ & 43.25 & 42.15 & 41.19 & 44.68 & 52.16 & 43.05 & 41.57 & 46.42 & 47.14 & 46.97 & 53.05 \\
\hline $\mathrm{TiO}_{2}$ & 0.48 & 1.35 & 0.23 & 0.60 & 0.15 & 1.27 & 0.73 & 0.67 & 1.47 & 1.12 & 0.17 \\
\hline $\mathrm{Al}_{2} \mathrm{O}_{3}$ & 9.76 & 9.82 & 11.77 & 9.43 & 3.11 & 9.65 & 10.71 & 7.13 & 7.19 & 7.02 & 2.54 \\
\hline $\mathrm{Cr}_{2} \mathrm{O}_{3}$ & 0.01 & 0.06 & 0.13 & 0.01 & 0.17 & 0.02 & 0.07 & 0.21 & 0.14 & 0.11 & 0.06 \\
\hline $\mathrm{FeO}$ & 22.75 & 19.28 & 21.98 & 20.71 & 14.23 & 21.90 & 22.89 & 20.11 & 16.99 & 16.92 & 12.82 \\
\hline $\mathrm{MnO}$ & 0.39 & 0.13 & 0.12 & 0.40 & 0.25 & 0.06 & 0.16 & 0.01 & 0.01 & 0.02 & 0.19 \\
\hline $\mathrm{MgO}$ & 6.98 & 9.26 & 7.85 & 8.52 & 14.47 & 7.98 & 6.67 & 9.94 & 11.13 & 11.90 & 15.55 \\
\hline $\mathrm{CaO}$ & 11.80 & 11.46 & 11.40 & 11.82 & 12.25 & 11.55 & 11.32 & 11.73 & 11.60 & 11.54 & 12.29 \\
\hline $\mathrm{Na}_{2} \mathrm{O}$ & 1.19 & 1.81 & 1.79 & 1.12 & 0.73 & 1.56 & 1.67 & 1.20 & 1.87 & 1.67 & 0.99 \\
\hline $\mathrm{K}_{2} \mathrm{O}$ & 1.59 & 1.24 & 1.22 & 0.04 & 0.22 & 1.21 & 1.24 & 0.66 & 0.84 & 0.81 & 0.21 \\
\hline Total & 98.20 & 96.56 & 97.68 & 97.33 & 97.74 & 98.25 & 97.03 & 98.08 & 98.38 & 98.08 & 97.87 \\
\hline
\end{tabular}

Ed—edenite, Fe-ed—ferroedenite, Mg-hn—magnesiohornblende, Fer-tsch—ferriantschermakite, act—actinolite, Mg-hast—magnesiohastingsite, Fe-hn—ferrohornblende, Fe-par-ferropargasite, Fe-tsch—ferrotschermakite. Analyst: T.F.C. Campos.

are the most common. Some zoned crystals have a core of ferrohornblende, magnesiohornblende, edenite or ferroedenite and a rim of $\mathrm{Mg}$-rich magnesiohornblende and rarely of subsolidus actinolite. A few crystals show a core of diopside and a rim of magnesiohornblende or ferroedenite. In other few crystals, actinolite probably replacing augite is rimmed by magnesiohornblende. However, in general, no relationship was found between crystallographic orientation and chemical composition, because most amphibole crystals are heterogeneous (e.g., Robinson et al., 1971; Droop, 1994). Amphibole crystals show patch domains enriched in $\mathrm{Mg}$, which may reflect the adjustment of amphibole to magmatic changes (e.g., Czamanske and Wones, 1973), but it is probably the result of near-solidus deformation and consequent partial reequilibration. Linear trends are found (Fig. 10), but amphibole of dioritic enclaves plots outside the $\mathrm{Fe}, \mathrm{Mg}$ and $\mathrm{Mg} /(\mathrm{Mg}+\mathrm{Fe})$ trends.

\subsection{Biotite}

Major and trace element compositions of biotites are given in Table 5. Their compositions correspond to those of biotites coexisting with pyroxene and amphibole (Nockolds, 1947) and are in accordance with the petrographic observations. Most of the granitoid rocks from the studied area contain Mg-biotite (Foster, 1960), but Fe-biotite is found in diorite, quartz-monzonite and quartz-monzodiorite. Biotite from microsyenogranite is the richest in $\mathrm{Al}$, which is in accordance with the mineralogical association. Variation diagrams of trace elements show linear trends (Fig. 11).

\subsection{Accessory minerals}

Chemical analyses of titanite, allanite and epidote are given in Tables 6 and 7. In general, there is no 

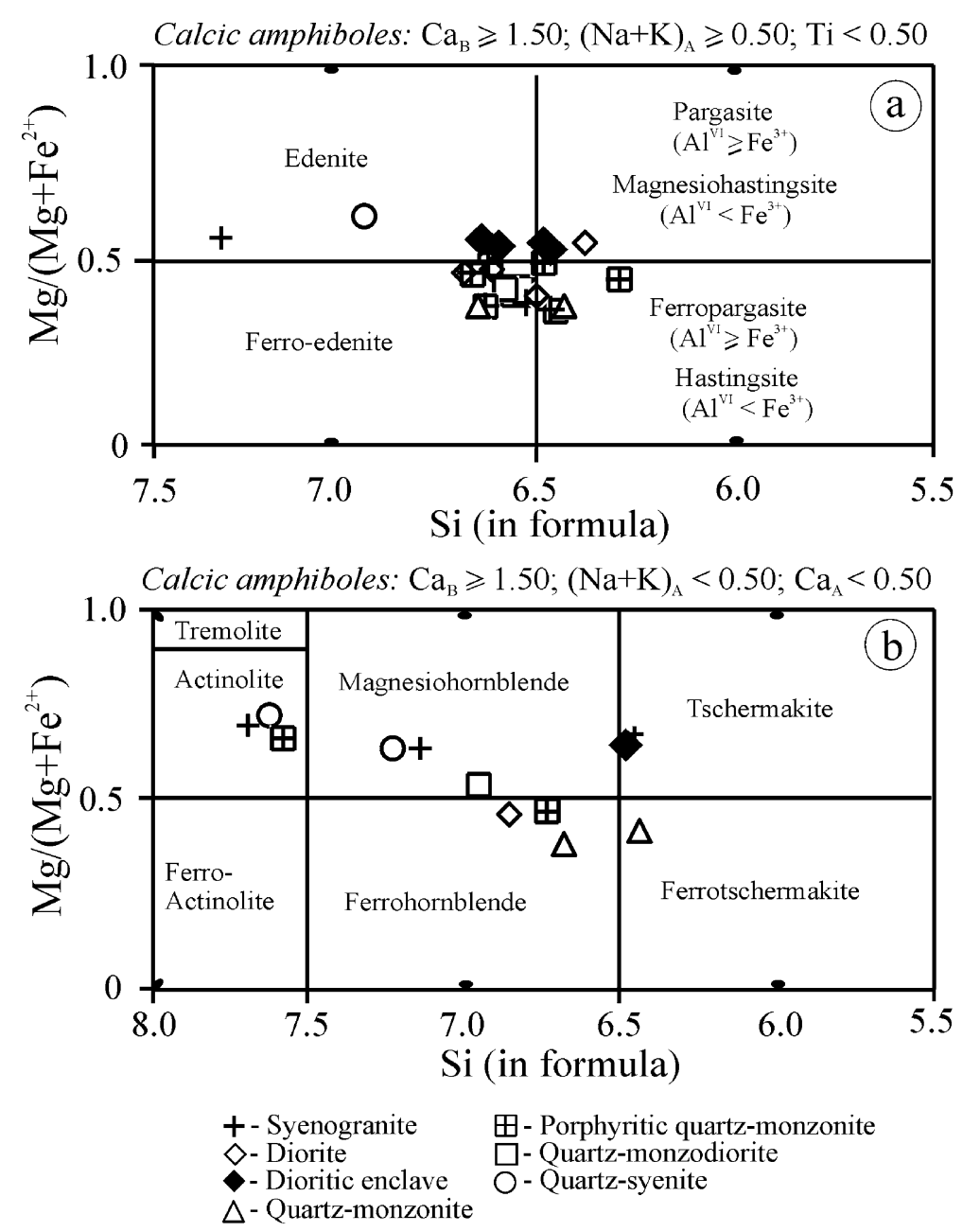

Fig. 9. Compositions of amphiboles of plutonic rocks from Rio Espinharas according to the IMA nomenclature (Leake et al., 1997).

significant distinction in composition of titanite from the different rock types, but titanite from the microsyenogranite tends to be the poorest in $\mathrm{Ti}$ and the richest in $\mathrm{Al}$ and $\mathrm{Mn}$, reflecting that the microsyenite is the most evolved plutonic rock in the pluton.

Allanite rimmed by epidote is poorer in $\mathrm{Ti}$ and $\mathrm{Ca}$, but generally richer in $\mathrm{Fe}$ than allanite from single crystals in the same rock type (Fig. 12). Linear trends are found for these elements, but $\mathrm{Ca}$ has a reverse behaviour in the allanite cores, probably due to their metamictic nature.

Epidote is commonly associated with amphibole and has a pistacite content $\mathrm{Ps}=\left[\mathrm{Fe}^{3+} /\left(\mathrm{Fe}^{3+}+\mathrm{Al}\right) \times\right.$
100 ], ranging between $26 \%$ and $30 \%$, which generally increases from core to rim. The pistacite content is similar to that of primary epidote from Brazilian granitoids (e.g., Sial et al., 1999; Campos et al., 2000).

Garnet of spessartite-almandine composition (Table 8) occurs in the microsyenogranite. The zoned crystals have a large rim generally richer in spessartite and andradite and poorer in almandine than the small core. The zonation is only found chemically.

Magnetite occurs in all granitoid rocks with end-member composition. Porphyritic quartz-monzonite also contains single crystals of ilmenite of similar chemical composition to the ilmenite $\left(\mathrm{Fe}_{0.89}^{2+}\right.$ 

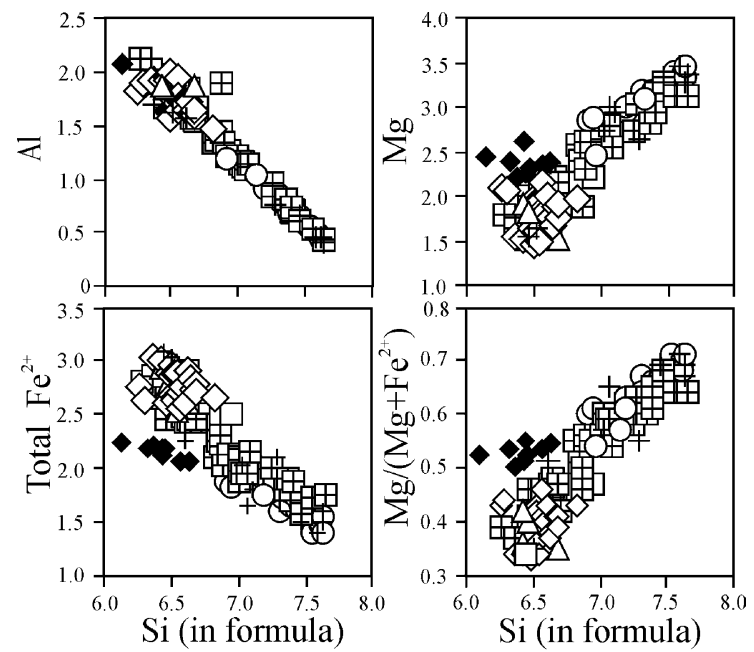

+ - Syenogranite

$\diamond$-Diorite

$\boxplus$ - Porphyritic quartz-monzonite

- Dioritic enclave

$\triangle$ - Quartz-monzonite

$\square$ - Quartz-monzodiorite

O- Quartz-syenite

Fig. 10. Variation diagrams of amphiboles of plutonic rocks from Rio Espinharas. $y$ axis is amphibole composition, whereas the $x$ axis is $\mathrm{SiO}_{2}$ content in the host rock.

$\left.\mathrm{Fe}_{0.09}^{3+} \mathrm{Mn}_{0.03} \mathrm{Mg}_{0.01}\right)_{\Sigma 1.02} \mathrm{Ti}_{0.96} \mathrm{O}_{3}$ exsolved from magnetite.

\section{Conditions of crystallization}

Amphibole rim compositions are used, but subsolidus actinolite rims are not taken into account for the calculations of pressure. Crystallization pressure of 5.7-7.1 kbar for all plutonic rocks was calculated from the Al-in-hornblende geobarometer of Schmidt (1992), except for quartz-syenite that yield a lower pressure of $2.9 \mathrm{kbar}$, which may reflect that the appropriate assemblage is not in equilibrium. Therefore, the pressure, generally, is close to the required 6 kbar for crystallization of magmatic epidote (Zen and Hammarstrom, 1988). Crystallization temperature 700-898 ${ }^{\circ} \mathrm{C}$ was calculated from the amphiboleplagioclase geothermometer (Holland and Blundy, 1994) with uncertainties of $\pm 40{ }^{\circ} \mathrm{C}$ (Table 9). Zircon saturation temperatures were calculated using the $\mathrm{Zr}$ contents of all plutonic rocks and the model of Watson and Harrison (1983). They range between 750 and $900{ }^{\circ} \mathrm{C}$. Temperatures above $860{ }^{\circ} \mathrm{C}$ are found in quartz-monzonite.
The two-feldspar geothermometer of Fuhrman and Lindsley (1988) was applied using the pressures calculated from compositions of amphibole. The temperatures, $410-774{ }^{\circ} \mathrm{C}$, are lower than those calculated from the amphibole-plagioclase geothermometer (Table 9) and most of them correspond to reequilibration of feldspars under subsolidus temperature. However, the highest temperature calculated from feldspar phenocrysts of porphyritic quartz-monzonite $\left(774{ }^{\circ} \mathrm{C}\right)$ is interpreted as magmatic, because it is in the range of those calculated by the amphiboleplagioclase geothermometer and zircon saturation temperatures.

\section{Discussion}

Syenogranite and microsyenogranite are weakly peraluminous and they have distinct $\left({ }^{87} \mathrm{Sr} /{ }^{86} \mathrm{Sr}\right)_{0}$ ratios, which are $0.7075-0.7088$ for syenogranite and $0.7093-0.7117$ for microsyenogranite (Table 2), suggesting that they represent two different pulses of granite magma, probably resulting from partial fusion of heterogeneous upper crustal materials. Microsyenogranite is younger than syenogranite as shown by field evidence.

In general, $\mathrm{TiO}_{2}$, total $\mathrm{FeO}, \mathrm{CaO}, \mathrm{V}$ and $\mathrm{Zn}$ decrease and $\mathrm{K}_{2} \mathrm{O}$ and $\mathrm{Rb}$ increase from diorite to syenogranite (Fig. 6). Most of the trends are linear, suggesting that quartz-monzonite, porphyritic quartz-monzonite, quartz-monzodiorite and quartz-syenite are hybrid rocks resulting from variable mixtures of dioritic and syenogranitic magmas, which is supported by the pseudo-errorchron (Fig. 8c). For the age of $601 \mathrm{Ma}$ yielded by the syenogranite errorchron (Fig. 8a), the calculated values of $\left({ }^{87} \mathrm{Sr} /{ }^{86} \mathrm{Sr}\right)_{0}$ ratios for quartzmonzonite, porphyritic quartz-monzonite, quartzmonzodiorite and quartz-syenite range between those for diorite and syenogranite, but they are closer to those for syenogranite (Table 2). However, curve trends with scatter for $\mathrm{Zr}, \mathrm{Sr}$ and $\mathrm{Ba}$ (Fig. 6) are difficult to produce simply by hybridization of two magmas. Lesher (1994) explains it experimentally by mixing for $\mathrm{Sr}$. As $\mathrm{Zr}, \mathrm{Sr}$ and $\mathrm{Ba}$ are variable in abundance in syenogranite (Table 1) mixing involving heterogeneous parent will not necessarily produce linear trends for these elements in a mixed-magma series (D’Lemos, 1996). 
Table 5

Average electron-microprobe analyses in wt.\% and trace elements in ppm of biotite of plutonic rocks from the Rio Espinharas pluton, northeastern Brazil

\begin{tabular}{|c|c|c|c|c|c|c|c|c|c|c|c|c|c|c|c|c|}
\hline \multirow[b]{2}{*}{$n$} & \multicolumn{2}{|c|}{ Syenogranite } & \multicolumn{2}{|l|}{ Diorite } & \multicolumn{2}{|c|}{$\begin{array}{l}\text { Dioritic } \\
\text { enclave }\end{array}$} & \multicolumn{2}{|c|}{$\begin{array}{l}\text { Quartz- } \\
\text { monzonite }\end{array}$} & \multicolumn{2}{|c|}{$\begin{array}{l}\text { Porphyritic } \\
\text { Quartz- } \\
\text { monzonite }\end{array}$} & \multicolumn{2}{|c|}{$\begin{array}{l}\text { Quartz- } \\
\text { monzodiorite }\end{array}$} & \multicolumn{2}{|l|}{$\begin{array}{l}\text { Quartz- } \\
\text { syenite }\end{array}$} & \multicolumn{2}{|c|}{ Microsyenogranite } \\
\hline & 76 & $\sigma$ & 85 & $\sigma$ & 19 & $\sigma$ & 68 & $\sigma$ & 127 & $\sigma$ & 18 & $\sigma$ & 56 & $\sigma$ & 33 & $\sigma$ \\
\hline $\mathrm{SiO}_{2}$ & 36.60 & 0.54 & 35.57 & 0.50 & 36.81 & 0.60 & 35.30 & 0.78 & 37.03 & 0.83 & 36.34 & 0.70 & 37.31 & 0.55 & 36.71 & 1.40 \\
\hline $\mathrm{TiO}_{2}$ & 2.03 & 0.24 & 2.71 & 0.19 & 3.91 & 0.30 & 2.34 & 0.29 & 2.14 & 0.40 & 2.34 & 1.00 & 1.87 & 0.19 & 2.01 & 0.10 \\
\hline $\mathrm{Al}_{2} \mathrm{O}_{3}$ & 14.85 & 0.43 & 14.63 & 0.13 & 14.73 & 0.10 & 14.77 & 0.27 & 14.22 & 0.27 & 14.60 & 0.80 & 13.82 & 0.55 & 15.71 & 0.10 \\
\hline $\mathrm{Fe}_{2} \mathrm{O}_{3}$ & 5.89 & 0.10 & 4.84 & 0.67 & n.d. & - & 5.48 & 0.88 & 3.91 & 0.76 & 5.21 & - & 5.51 & 0.76 & n.d. & - \\
\hline $\mathrm{FeO}$ & 16.67 & 2.15 & 19.96 & 1.39 & 18.60 & 1.40 & 19.97 & 1.73 & 16.82 & 1.58 & 17.85 & 1.00 & 14.69 & 0.24 & 19.50 & 1.20 \\
\hline $\mathrm{MnO}$ & 0.07 & 0.06 & 0.06 & 0.04 & - & - & 0.03 & 0.01 & 0.03 & 0.02 & - & - & - & - & 0.36 & 0.40 \\
\hline $\mathrm{MgO}$ & 11.08 & 0.75 & 8.72 & 0.82 & 12.46 & 0.80 & 9.50 & 0.86 & 12.19 & 1.21 & 9.75 & 1.10 & 13.53 & 0.13 & 11.62 & 0.80 \\
\hline $\mathrm{CaO}$ & 0.09 & 0.03 & 0.11 & 0.04 & 0.14 & 0.20 & 0.10 & 0.05 & 0.09 & 0.03 & 0.08 & - & 0.15 & - & 0.18 & - \\
\hline $\mathrm{Na}_{2} \mathrm{O}$ & 0.41 & 0.04 & 0.39 & 0.11 & 0.46 & 0.20 & 0.39 & 0.05 & 0.39 & 0.07 & 0.38 & 0.10 & 0.41 & 0.02 & 0.51 & 0.10 \\
\hline $\mathrm{K}_{2} \mathrm{O}$ & 9.46 & 0.06 & 9.29 & 0.21 & 9.32 & 0.20 & 9.28 & 0.09 & 9.40 & 0.16 & 9.35 & 0.10 & 9.52 & 0.11 & 9.30 & 0.10 \\
\hline $\mathrm{Cl}$ & 0.01 & - & 0.02 & - & n.d. & & 0.03 & - & 0.03 & - & 0.02 & - & 0.03 & - & n.d. & \\
\hline $\mathrm{F}$ & 0.09 & - & 0.02 & - & n.d. & & 0.04 & - & 0.06 & - & 0.03 & - & 0.06 & - & n.d. & \\
\hline & 97.25 & & 96.32 & & 96.43 & & 97.23 & & 96.31 & & 95.95 & & 96.90 & & 95.90 & \\
\hline $\mathrm{O} \equiv \mathrm{Cl}$ & - & & - & & - & & 0.01 & & 0.01 & & - & & 0.01 & & - & \\
\hline $\mathrm{O} \equiv \mathrm{F}$ & 0.04 & & 0.01 & & - & & 0.02 & & 0.03 & & 0.01 & & 0.03 & & - & \\
\hline Total & 97.24 & & 96.31 & & 96.43 & & 97.20 & & 96.27 & & 95.94 & & 96.86 & & 95.90 & \\
\hline$n^{\prime}$ & 5 & $\sigma$ & 8 & $\sigma$ & & & 3 & & 14 & $\sigma$ & 1 & & 2 & & & \\
\hline $\mathrm{Cr}$ & 140 & 28 & 40 & 8 & & & 55 & & 448 & 297 & 71 & & 858 & & & \\
\hline $\mathrm{V}$ & 273 & 42 & 361 & 23 & & & 310 & & 360 & 31 & 384 & & 343 & & & \\
\hline $\mathrm{Nb}$ & 15 & 3 & $*$ & & & & 4 & & 8 & 2 & $*$ & & 7 & & & \\
\hline $\mathrm{Zn}$ & 471 & 8 & 57 & 2 & & & 61 & & 115 & 25 & 84 & & 173 & & & \\
\hline $\mathrm{Ni}$ & 48 & 6 & 55 & 14 & & & 18 & & 325 & 158 & 179 & & 600 & & & \\
\hline $\mathrm{Zr}$ & 194 & 73 & 90 & 36 & & & 51 & & 49 & 55 & 8 & & 47 & & & \\
\hline $\mathrm{Cu}$ & 24 & 13 & 15 & 4 & & & 6 & & 37 & 18 & 11 & & 77 & & & \\
\hline $\mathrm{Sc}$ & 32 & 8 & 5 & 1 & & & 18 & & 9 & 3 & 9 & & 8 & & & \\
\hline $\mathrm{Y}$ & 62 & 12 & 36 & 2 & & & 40 & & 42 & 5 & 34 & & 47 & & & \\
\hline $\mathrm{Sr}$ & 26 & 5 & 28 & 2 & & & 26 & & 29 & 4 & 24 & & 37 & & & \\
\hline $\mathrm{Ba}$ & 828 & 235 & 3657 & 397 & & & 1732 & & 2043 & 222 & 3022 & & 785 & & & \\
\hline $\mathrm{Rb}$ & 1389 & 325 & 310 & 53 & & & 540 & & 618 & 135 & 384 & & 704 & & & \\
\hline
\end{tabular}

$n$ : Number of points; $n^{\prime}$ : number of concentrates; $\sigma$ : standard deviation; n.d.: not determined; *: below the limit of sensitivity. Analyst: T.F.C. Campos.

There are some field and petrographic lines of evidence of a mixing process. Most of the plutonic rocks contain dioritic enclaves of round or ovoid shape. Heterogeneous gradational zones are found along several contacts between different rock types. Skeletal morphology of amphibole and acicular habit of apatite are indicative of rapid growth and/or undercooling, consistent with rapid fluctuations in magma conditions and, hence, with mixing.

Linear trends for some major and trace elements may correspond to fractional crystallization, but the bell-shaped curves for $\mathrm{Zr}, \mathrm{Sr}, \mathrm{Ba}, \mathrm{Sr} /(\mathrm{Ca}+\mathrm{K})$ and $\mathrm{Ba} /$ $(\mathrm{Ca}+\mathrm{K})$ (Fig. 6) cannot be produced by this mecha- nism. The chondrite normalized REE abundances of plutonic rocks from Rio Espinharas are similar (Fig. 7a), suggesting that fractional crystallization was not important. The $\left({ }^{87} \mathrm{Sr} /{ }^{86} \mathrm{Sr}\right)_{0}$ ratio of the diorite $(0.7064)$ is lower than that of syenogranite $(0.7075-$ 0.7088 ) for the age of $601 \mathrm{Ma}$ (Table 2), which indicates that diorite and syenogranite do not have a common origin.

The bell-shaped, concave-downward curves for $\mathrm{Zr}, \mathrm{Sr}, \mathrm{Ba}, \mathrm{Sr} /(\mathrm{Ca}+\mathrm{K})$ and $\mathrm{Ba} /(\mathrm{Ca}+\mathrm{K})$ (Fig. 6) may be interpreted to consist of two trends: (a) rocks ranging from diorite to syenogranite define a positive linear trend in each diagram representing mix- 


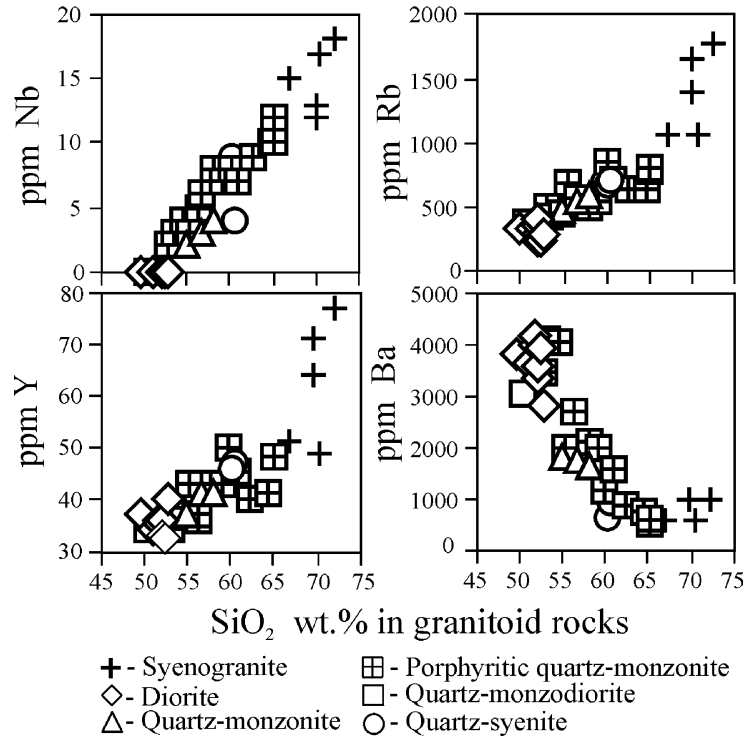

Fig. 11. Variation diagrams of biotites of plutonic rocks from Rio Espinharas. $y$ axis is biotite composition, whereas the $x$ axis is $\mathrm{SiO}_{2}$ content in the host rock.

ing, but with some scatter attributed to variation in the chemical compositions of end-members and small postcrystallization chemical changes; (b) syenogranite and microsyenogranite define a negative trend in each diagram for $\mathrm{Zr}, \mathrm{Sr}, \mathrm{Ba}, \mathrm{Sr} /(\mathrm{Ca}+\mathrm{K})$ and $\mathrm{Ba} /(\mathrm{Ca}+\mathrm{K})$. Although syenogranite and microsyenogranite correspond to two different pulses of granite magma, the plots of some of their samples overlap and the negative trends may correspond to fractional crystallization better defined in the syenogranite.

Microgranular dioritic enclaves found in the quartz-monzonite are richer in $\mathrm{Mg}, \mathrm{Ca}, \mathrm{Sc}$ and poorer in $\mathrm{Si}, \mathrm{K}, \mathrm{Sr}$ and $\mathrm{Ba}$ than diorite (Table 1). Therefore, two dioritic magmas are distinct, with different elemental concentrations. The dioritic enclaves plot outside the linear trends in the Ti diagram of rocks (Fig. 6) and in $\mathrm{Fe}^{2+}, \mathrm{Mg}$ and $\mathrm{Mg} /\left(\mathrm{Mg}+\mathrm{Fe}^{2+}\right)$ diagrams of amphibole (Fig. 10). This suggests that they cannot represent the end-member basic magma for the mixing process. Dioritic enclaves are not related to host quartz-monzonite by fractional crystallization (Figs. $6,7 \mathrm{~b}$ and 10 ). Furthermore, dioritic enclaves are not restites, because they do not contain rather uniform calcic plagioclase cores, the amphibole is subhedral with poikilitic texture, indicating that it crystallized from the melt and the enclaves and host quartzmonzonite do not define linear trends for all elements (Fig. 6).

It can be considered that different injections of basic magma took place. Some intruded syenogranite magma during its crystallization, but others intruded partially crystallized hybrid magmas, e.g., quartzmonzonite. During thermal equilibration there was rapid crystallization of the basic magma and dioritic enclaves were formed in the quartz-monzonite. As the basic magma releases heat along the boundaries between both magmas, it assimilates acid magma probably partially crystallized. Deep-seated assimilation took place. The absence of well-defined linear mixing trends for all elements indicates that perfect mixing between the upper crustal-derived syenogranitic magma and upper mantle-derived dioritic magma did not occur (Fig. 6). Homogenization of magmas was not reached, because there is scattering of isotopic ratios and, consequently, they do not define isochrones (Fig. 8a, c). The dioritic magma as a whole needs more time to obtain equilibrium than at a local scale of small blebs and may fractionate (Poli and Tommasini, 1991). However, at Rio Espinharas pluton, there is no evidence of fractionation of dioritic magma, which is better shown by the $\left({ }^{87} \mathrm{Sr} /{ }^{86} \mathrm{Sr}\right)_{0}$ of diorite that is distinct from those of the other plutonic rocks (Table 2).

In the rocks ranging from diorite to syenogranite, those richer in mafic minerals may be interpreted as

Table 6

Average electron microprobe of titanite of plutonic rocks from the Rio Espinharas pluton, northeastern Brazil

\begin{tabular}{|c|c|c|c|c|c|c|c|c|}
\hline & A & B & $\mathrm{C}$ & $\mathrm{D}$ & E & F & G & $\mathrm{H}$ \\
\hline $\mathrm{O}_{2}$ & 30.18 & 30.25 & 29.85 & 30.25 & 30.19 & 30.14 & 30.24 & 30.06 \\
\hline $\mathrm{iO}_{2}$ & 37.20 & 38.09 & 37.50 & 38.54 & 38.09 & 37.59 & 38.35 & 36.26 \\
\hline $\mathrm{l}_{2} \mathrm{O}_{3}$ & 1.90 & 1.42 & 1.46 & 1.33 & 1.35 & 1.56 & 1.27 & 2.37 \\
\hline $\mathrm{O}$ & 1.73 & 1.12 & 1.18 & 1.18 & 1.20 & 0 & 1.41 & 2.06 \\
\hline $\mathrm{MnO}$ & 0.03 & 0.07 & 0.08 & 0.05 & 0.02 & 0.07 & 0.02 & 0.13 \\
\hline $\mathrm{MgO}$ & 0.18 & 0.13 & 0.07 & 0.07 & 0.06 & 0.07 & 0.06 & 0.10 \\
\hline $\mathrm{aO}$ & 27.31 & 27.44 & 27.09 & 27.14 & 27.55 & 27.55 & 27.49 & 27.20 \\
\hline $\mathrm{Na}_{2} \mathrm{O}$ & 0.10 & 0.14 & 0.06 & 0.09 & 0.06 & 0.03 & 0.06 & 0.16 \\
\hline $\mathrm{K}_{2} \mathrm{O}$ & 0.04 & 0.03 & 0.01 & 0.01 & 0.01 & 0.01 & 0.02 & 0.06 \\
\hline otal & 98.67 & 98.69 & 97.30 & 98.66 & 98.53 & 98.42 & 98.92 & 98.40 \\
\hline
\end{tabular}

A: syenogranite; B: diorite; $\mathrm{C}$ : diorite enclave; D: quartzmonzonite; E: porphyritic quartz-monzonite; F: quartz-monzodiorite; G: quartz-syenite; H: microsyenogranite. Analyst: Thomas F.C. Campos. 
Table 7

Average electron microprobe analyses of allanite and epidote of the plutonic rocks from the Rio Espinharas pluton, northeastern Brazil

\begin{tabular}{|c|c|c|c|c|c|c|c|c|c|c|c|c|c|c|}
\hline & \multicolumn{8}{|c|}{ Allanite } & \multicolumn{6}{|c|}{ Epidote } \\
\hline & \multicolumn{2}{|l|}{ A } & \multicolumn{2}{|l|}{ B } & \multicolumn{2}{|l|}{$\mathrm{C}$} & \multicolumn{2}{|l|}{ D } & \multirow[t]{2}{*}{$\mathrm{A}$} & \multirow[t]{2}{*}{ B } & \multirow[t]{2}{*}{$\mathrm{C}$} & \multirow[t]{2}{*}{$\mathrm{D}$} & \multirow[t]{2}{*}{$\mathrm{E}$} & \multirow[t]{2}{*}{ F } \\
\hline & $\mathrm{s}$ & $\mathrm{z}$ & $\mathrm{s}$ & $\mathrm{z}$ & $\mathrm{s}$ & z & $\mathrm{s}$ & $\mathrm{z}$ & & & & & & \\
\hline $\mathrm{SiO}_{2}$ & 30.21 & 33.23 & 27.68 & 34.14 & 30.71 & 30.09 & 30.08 & 29.99 & 37.77 & 37.68 & 37.11 & 36.21 & 37.02 & 37.26 \\
\hline $\mathrm{TiO}_{2}$ & 1.55 & 0.08 & 0.76 & 0.07 & 2.29 & 1.26 & 1.40 & 1.26 & 0.07 & 0.06 & 0.05 & 0.22 & 0.07 & 0.08 \\
\hline $\mathrm{Al}_{2} \mathrm{O}_{3}$ & 18.05 & 21.87 & 16.38 & 23.98 & 18.00 & 17.00 & 16.99 & 16.50 & 23.12 & 22.81 & 22.87 & 22.33 & 23.34 & 23.07 \\
\hline $\mathrm{FeO}$ & 13.40 & 12.97 & 12.21 & 12.04 & 13.71 & 15.55 & 12.49 & 15.53 & 12.71 & 13.20 & 12.33 & 12.69 & 12.25 & 12.02 \\
\hline $\mathrm{MnO}$ & 0.35 & 0.03 & 0.35 & 0.24 & 0.53 & 0.35 & 0.24 & 0.30 & 0.18 & 0.20 & 0.19 & 0.32 & 0.19 & 0.14 \\
\hline $\mathrm{MgO}$ & 0.07 & 0.34 & 0.03 & 0.41 & 0.68 & 0.64 & 0.06 & 0.60 & - & - & - & 0.10 & - & - \\
\hline $\mathrm{CaO}$ & 17.56 & 15.35 & 16.98 & 14.53 & 11.11 & 12.31 & 17.03 & 12.22 & 23.20 & 23.24 & 22.72 & 20.97 & 22.92 & 23.58 \\
\hline $\mathrm{Na}_{2} \mathrm{O}$ & 0.04 & 0.14 & 0.19 & 0.29 & 0.40 & 0.01 & 0.19 & - & - & - & 0.03 & 0.47 & - & - \\
\hline $\mathrm{K}_{2} \mathrm{O}$ & 0.07 & 0.09 & 0.22 & 0.14 & 0.27 & - & 0.09 & - & - & 0.04 & - & 0.07 & - & - \\
\hline Total & 81.30 & 84.10 & 74.80 & 85.84 & 77.70 & 77.21 & 78.57 & 76.40 & 97.05 & 97.23 & 95.30 & 93.38 & 95.79 & 96.15 \\
\hline
\end{tabular}

A: syenogranite; B: diorite; C: quartz-monzonite; D: porphyritic quartz-monzonite; E: quartz-monzodiorite; F: quartz-syenite. s: single crystal; z: core of zoned crystal. Analyst: Thomas F.C. Campos.

cumulates, because some trends, particularly for $\mathrm{Zr}$, $\mathrm{Sr}, \mathrm{Ba}, \mathrm{Sr} /(\mathrm{Ca}+\mathrm{K})$ and $\mathrm{Ba} /(\mathrm{Ca}+\mathrm{K})$ (Fig. 6), show a marked inflection corresponding to the appearance of

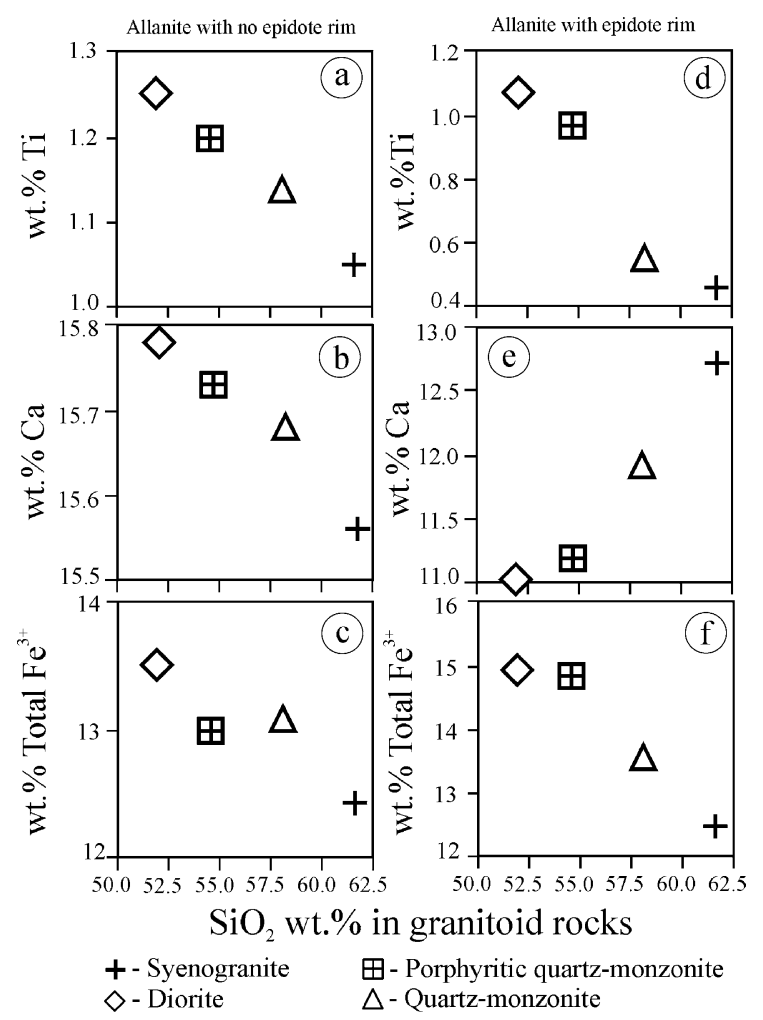

Fig. 12. Variation diagrams of allanites of plutonic rocks from Rio Espinharas. (a, b, c) Single crystal; (d, e, f) allanite core rimmed by epidote. new liquidus carrying those elements. The scatter in $\mathrm{Sr}$ and $\mathrm{Ba}$ can be caused by variations in proportions of plagioclase and amphibole.

\subsection{The hybridization model}

The binary mixing test of Fourcade and Allègre (1981) was applied here, using the average compositions of the least silicic samples of diorite and of the most silicic samples of syenogranite to represent the least contaminated basic magma and acid magma, respectively. The equation $C_{\mathrm{m}}{ }^{i}-C_{\mathrm{B}}{ }^{i}=x\left(C_{\mathrm{A}}{ }^{i}-C_{\mathrm{B}}{ }^{i}\right)$ was used for each element $(i)$, where subscripts $m$, $\mathrm{A}$ and $\mathrm{B}$ refer to the mixture, component $\mathrm{A}$ and $\mathrm{B}$, respectively; $x$ being the weight proportion of component A. The plot $C_{\mathrm{m}}{ }^{i}-C_{\mathrm{B}}{ }^{i}$ vs. $C_{\mathrm{A}}{ }^{i}-C_{\mathrm{B}}{ }^{i}$ defines a straight line, whose slope gives the mass proportions of the mixture.

The contents of $\mathrm{SiO}_{2}, \mathrm{Rb}$ increase and of $\mathrm{TiO}_{2}$, $\mathrm{FeO}, \mathrm{CaO}$ and $\mathrm{V}$ decrease with decrease in weight fraction of dioritic magma (Fig. 13), and all trends are linear. The calculated contents of trace elements are close to the analytical data, except for $\mathrm{Ba}$ and $\mathrm{Sr}$ in some rocks (Fig. 14).

\subsection{The fractional crystallization model}

The two least silicic samples of the syenogranite with average $\mathrm{SiO}_{2}$ of 61.63 wt.\%, and $\mathrm{P}_{2} \mathrm{O}_{5}$ close to that of dioritic magma seem to be contaminated syenogranite magma, and they are not good represen- 
Table 8

Representative electron microprobe analyses of garnet of microsyenogranite from the Rio Espinharas pluton, northeastern Brazil

\begin{tabular}{|c|c|c|c|c|c|c|c|c|c|}
\hline & \multicolumn{2}{|l|}{$\mathrm{a}$} & \multicolumn{2}{|l|}{$\mathrm{b}$} & \multicolumn{2}{|l|}{$\mathrm{c}$} & \multicolumn{2}{|l|}{$\mathrm{d}$} & \multirow{2}{*}{$\frac{\mathrm{e}}{\text { Single }}$} \\
\hline & $\operatorname{Rim}$ & Core & Rim & Core & Rim & Core & Rim & Core & \\
\hline $\mathrm{SiO}_{2}$ & 36.28 & 36.60 & 36.59 & 36.64 & 36.26 & 36.25 & 36.45 & 36.54 & 36.74 \\
\hline $\mathrm{TiO}_{2}$ & 0.17 & 0.19 & 0.20 & 0.20 & 0.19 & 0.12 & 0.25 & 0.26 & 0.17 \\
\hline $\mathrm{Al}_{2} \mathrm{O}_{3}$ & 19.77 & 19.84 & 19.79 & 19.89 & 19.62 & 19.75 & 19.71 & 19.73 & 19.87 \\
\hline $\mathrm{Cr}_{2} \mathrm{O}_{3}$ & 0.02 & 0.02 & 0.02 & 0.04 & 0.05 & 0.02 & 0.02 & 0.02 & 0.04 \\
\hline $\mathrm{Fe}_{2} \mathrm{O}_{3}$ & 1.31 & 0.74 & 1.15 & 1.06 & 1.21 & 1.07 & 1.21 & 1.22 & 1.13 \\
\hline $\mathrm{FeO}$ & 16.07 & 16.75 & 15.53 & 16.38 & 15.32 & 15.46 & 15.50 & 15.63 & 16.14 \\
\hline $\mathrm{MnO}$ & 24.46 & 23.91 & 25.35 & 24.53 & 25.35 & 24.99 & 25.14 & 25.36 & 24.36 \\
\hline $\mathrm{MgO}$ & 0.54 & 0.52 & 0.55 & 0.52 & 0.38 & 0.43 & 0.39 & 0.41 & 0.51 \\
\hline $\mathrm{CaO}$ & 1.55 & 1.61 & 1.62 & 1.44 & 1.45 & 1.50 & 1.68 & 1.47 & 1.85 \\
\hline Total & 100.17 & 100.18 & 100.80 & 100.70 & 99.83 & 99.59 & 100.35 & 100.64 & 100.81 \\
\hline Percent almandine & 36.10 & 37.83 & 34.33 & 36.96 & 34.93 & 35.40 & 35.04 & 35.23 & 36.37 \\
\hline Percent andratite & 4.08 & 2.28 & 3.55 & 3.27 & 3.77 & 3.33 & 3.75 & 3.77 & 3.47 \\
\hline Percent grossular & 0.50 & 2.43 & 1.20 & 0.95 & 0.52 & 1.10 & 1.19 & 0.54 & 1.92 \\
\hline Percent pyrope & 2.22 & 2.12 & 2.24 & 2.12 & 1.56 & 1.77 & 1.59 & 1.67 & 2.07 \\
\hline Percent spessartite & 57.11 & 55.34 & 58.68 & 56.71 & 59.22 & 58.39 & 58.42 & 58.79 & 56.16 \\
\hline Percent C & 99.46 & 100.21 & 99.67 & 99.97 & 99.97 & 99.94 & 99.82 & 99.83 & 100.06 \\
\hline
\end{tabular}

Percent C-percentage of cations allocated to end-member molecules. Analyst: T.F.C. Campos.

tatives of the parental magma. However, the three other samples of syenogranite with average $\mathrm{SiO}_{2}$ of 66.60 wt. $\%$ have $\mathrm{P}_{2} \mathrm{O}_{5}$ content significantly lower than that of diorite and are the richest in $\mathrm{Zr}$ contents. Thus, they were selected to represent the parental magma in our modelling. The average composition of the two most silicic samples of syenogranite with $\mathrm{SiO}_{2}=73.07$ wt. $\%$ was taken as residual liquid. The least-square regression method was applied to model major elements taking pure anorthite, albite and quartz, and the analyzed compositions of microcline, edenite, biotite, titanite and magnetite. The anorthite content of plagioclase of the cumulate $(\mathrm{An}=22 \pm 4)$ is similar to the highest value $(\mathrm{An}=19)$ found in plagioclase of syenogranite (Table 3). The residual values $(R)$ for each oxide is low (Table 10). The fractionating phases are plagioclase, microcline, edenite, biotite and titanite.

The trace elements $\mathrm{Sr}, \mathrm{Ba}$ and $\mathrm{Rb}$ were modelled using the equations for perfect (or Rayleigh) fractional crystallization and equilibrium crystallization (Tindle and Pearce, 1981). The modal composition of cumulate and the weight fraction of melt remaining during fractional crystallization (Table 10), the distribution coefficients compiled by Rollinson (1995) and the average $\mathrm{Sr}, \mathrm{Ba}$ and $\mathrm{Rb}$ contents of the samples selected to represent the parental magma were used. The calculated $\mathrm{Sr}, \mathrm{Ba}$ and $\mathrm{Rb}$ contents based on the

Table 9

Some conditions of crystallization of plutonic rocks from the Rio Espinharas pluton, northeastern Brazil

\begin{tabular}{|c|c|c|c|c|c|c|c|}
\hline & Syenogranite & Diorite & $\begin{array}{l}\text { Dioritic } \\
\text { enclaves }\end{array}$ & $\begin{array}{l}\text { Quartz- } \\
\text { monzonite }\end{array}$ & $\begin{array}{l}\text { Porphyritic } \\
\text { quartz-monzonite }\end{array}$ & $\begin{array}{l}\text { Quartz- } \\
\text { monzodiorite }\end{array}$ & $\overline{\text { Quartz-syenite }}$ \\
\hline Pressure (kbar) & 5.8 & $5.9-6.5$ & $5.9-6.8$ & $5.7-6.0$ & $5.8-7.1$ & $5.7-6.3$ & 2.9 \\
\hline $\begin{array}{l}\text { Temperatures }\left({ }^{\circ} \mathrm{C}\right) \\
\text { amphibole-plagioclase }\end{array}$ & $782-798$ & $785-850$ & $788-898$ & $742-845$ & $774-815$ & $750-785$ & $700-760$ \\
\hline Feldspars & - & - & - & - & - & - & - \\
\hline Phenocrysts & - & $575-732$ & - & - & $623-774$ & - & - \\
\hline Matrix & $473-706$ & $575-732$ & - & $495-698$ & $497-629$ & $524-667$ & $476-621$ \\
\hline Xenocrysts & - & - & - & $458-638$ & $493-632$ & $512-641$ & $410-576$ \\
\hline
\end{tabular}

Pressure was calculated from the Al-in-hornblende geobarometer of Schmidt (1992). Amphibole-plagioclase geothermometer of Holland and Blundy (1994) and two-feldspar geothermometer of Fuhrman and Lindsley (1988) were used. 

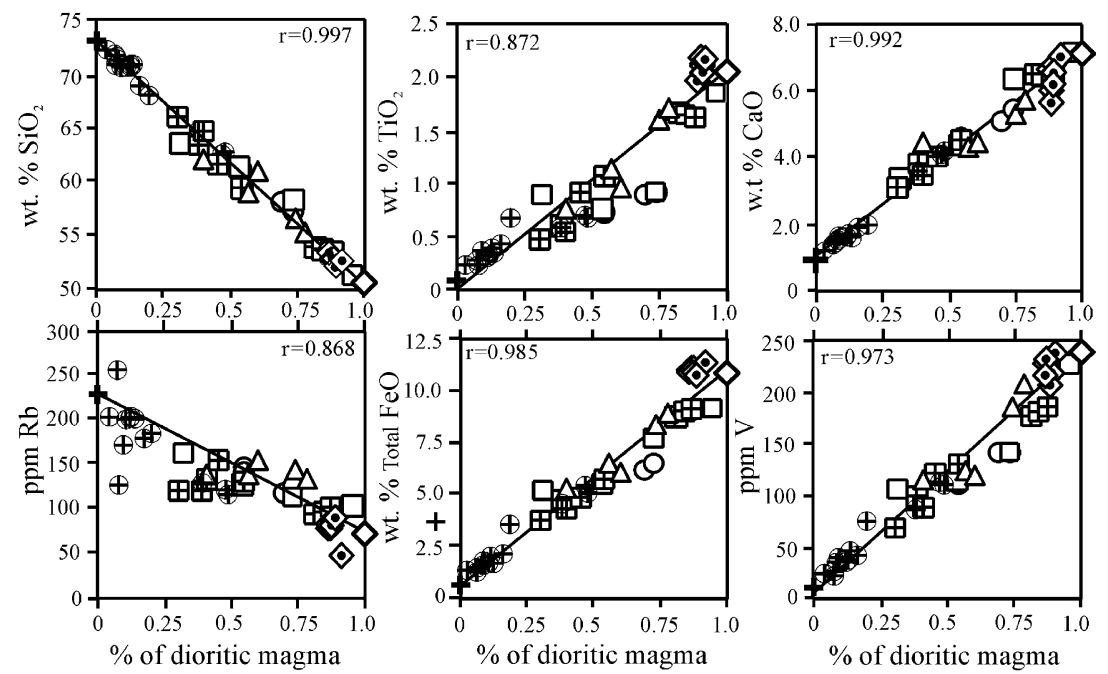
+- Syenogranitic magma $\oplus$ - Contaminated syenogranite 界- Porphyritic quartz-monzonite $\square$ - Quartz-monzodiorite
$\diamond$ - Dioritic magma $\diamond$ - Contaminated diorite $\triangle$ - Quartz-monzonite $\quad$ - Quartz-syenite

Fig. 13. Plot of some analytical contents vs. the weight fraction of dioritic magma involved in the binary mixing process for hybrid plutonic rocks from Rio Espinharas.

Rayleigh fractional crystallization are the closest to the analytical data and are given in Table 10. The differences found between the calculated and deter-
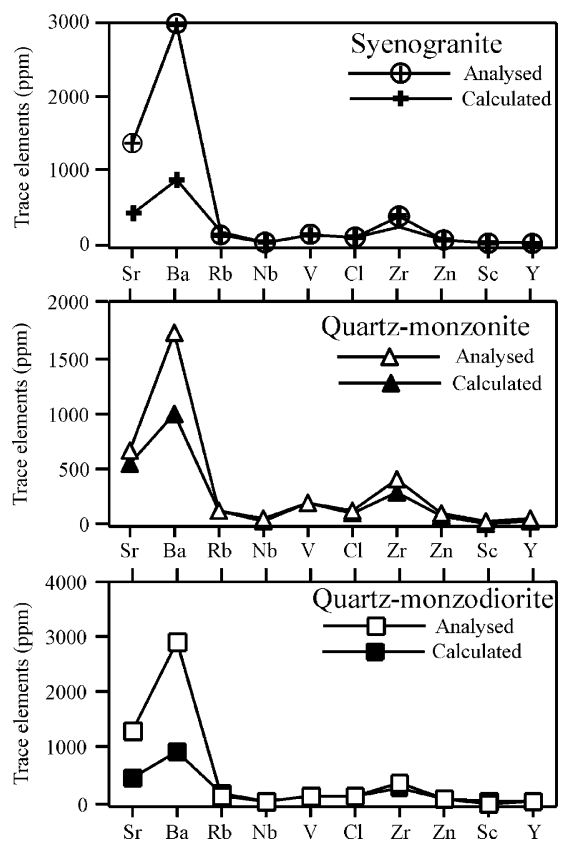

mined values of $\mathrm{Sr}, \mathrm{Ba}$ and $\mathrm{Rb}$ may be attributed to the partition coefficients in this system that are poorly known. However, the calculated $\mathrm{Sr}$ value is higher,

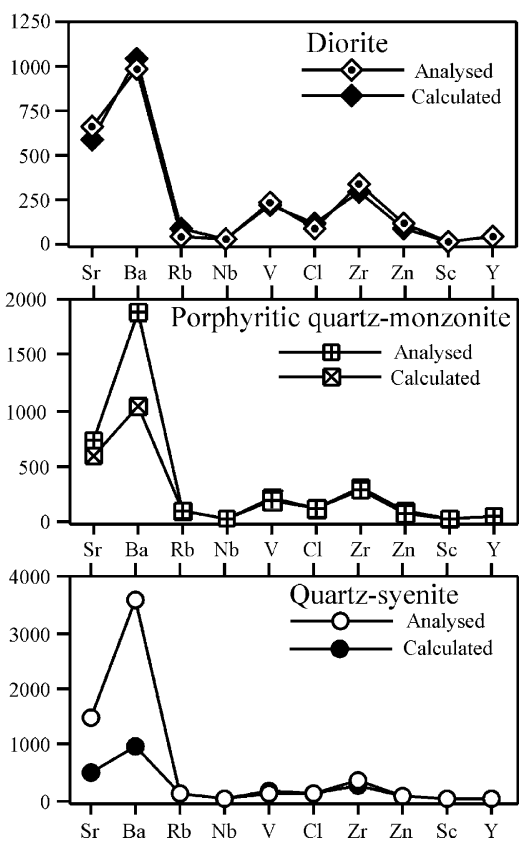

Fig. 14. Comparison between analyzed and calculated trace elements contents of hybrid plutonic rocks from Rio Espinharas. 
Table 10

Comparison of the determined and calculated data to test fractional crystallization within syenogranite from the Rio Espinharas pluton

\begin{tabular}{lccl}
\hline & \multicolumn{3}{l}{ Parent magma } \\
\cline { 2 - 4 } & Determined & Calculated & $R$ \\
\hline $\mathrm{SiO}_{2}$ & 66.60 & 66.60 & -0.1 \\
$\mathrm{TiO}_{2}$ & 0.56 & 0.50 & +0.6 \\
$\mathrm{Al}_{2} \mathrm{O}_{3}$ & 15.45 & 15.40 & +0.4 \\
$\mathrm{Total} \mathrm{Fe}_{2} \mathrm{O}_{3}$ & 3.62 & 3.70 & -0.4 \\
$\mathrm{MgO}$ & 2.45 & 2.30 & +2.0 \\
$\mathrm{CaO}$ & 2.47 & 2.50 & -0.8 \\
$\mathrm{Na}$ & 3.90 & 4.00 & -0.6 \\
$\mathrm{~K}_{2} \mathrm{O}$ & 4.95 & 5.00 & -0.4
\end{tabular}

Wt.\% of melt remaining after fractional crystallization $0.605 \pm 0.05$

Composition of cumulate

\begin{tabular}{lr}
\hline Plagioclase & $36.7 \pm 6$ \\
Microcline & $23.0 \pm 5$ \\
Edenite & $24.3 \pm 3$ \\
Biotite & $15.2 \pm 3$ \\
Titanite & $0.8 \pm 1$
\end{tabular}

\begin{tabular}{lll} 
& \multicolumn{2}{l}{ Most silicic samples } \\
\cline { 2 - 3 } $\mathrm{ppm}$ & Determined & Calculated \\
\hline $\mathrm{Sr}$ & 260 & 299 \\
$\mathrm{Ba}$ & 738 & 665 \\
$\mathrm{Rb}$ & 234 & 215 \\
\hline
\end{tabular}

$R$ represents the prediction of the error on the calculated value, so represents $X_{\text {determined }}-X_{\text {calculated }} / \sigma X_{\text {determined. }}$.

while the calculated $\mathrm{Rb}$ result is lower than the analytical data, suggesting that the behaviour of these elements is controlled by magmatic fluids, because they cause decrease in $\mathrm{Sr}$ and increase in $\mathrm{Rb}$. Therefore, the descent line on the $\mathrm{Zr}, \mathrm{Sr}, \mathrm{Ba}, \mathrm{Sr} /(\mathrm{Ca}+\mathrm{K})$ and $\mathrm{Ba} /(\mathrm{Ca}+\mathrm{K})$ diagrams of rocks (Fig. 6) is mainly explained by fractional crystallization within syenogranite magma.

\subsection{The probable sequence of events}

The sequence of events that led to the formation of different rock types in the Espinharas pluton would have been the following: (a) upper mantlederived magma underplating the crust supplied heat necessary for upper crust partial melting to originate syenogranite, but limited mixing probably took place between dioritic and syenogranitic magmas due to intrusion of mantle-derived magma through faults, as the Rio Espinharas pluton crops out between two megafaults (Figs. 1b and 2); (b) syenogranitic magma evolved by fractional crystallization; (c) dioritic magma intruded the partially crystallized syenogranitic magma and, consequently, there was coexistence of partial molten basic and acid magmas, as supported by field evidence (Fig. 3b); (d) the syenogranitic magma and dioritic magma became progressively hybrid (Fig. 13), giving rise to quartzmonzonite, porphyritic quartz-monzonite, quartzmonzodiorite and quartz-syenite, which were formed by mixing of different proportions of dioritic magma and syenogranite magma (Figs. 13, 14); (e) dioritic enclaves represent the mingling/mixing process, but with dominance of mingling; (f) microsyenogranite was generated by partial melting of crustal materials and mixing with a small content of mantle-derived component, and intruded all rocks in the pluton.

\section{Conclusions}

(1) Diorite, quartz-monzonite, porphyritic quartzmonzonite, quartz-monzodiorite, quartz-syenite and syenogranite have similar mineralogical association only in different proportions. They contain quartz, plagioclase, K-feldspar, amphibole, biotite, titanite, allanite, magnetite and rare ilmenite. Pyroxene was found in all of them, except for in the syenogranite. Commonly, they show gradational contacts among each other rock type.

(2) Most of them, except diorite, contain microgranular enclaves, which are rounded or ovoid and finer-grained than host-rock.

(3) $\mathrm{TiO}_{2}$, total $\mathrm{FeO}, \mathrm{CaO}, \mathrm{V}, \mathrm{Zn}$ and $\mathrm{Rb}$ contents of the rocks show linear variation trends, but $\mathrm{Zr}, \mathrm{Sr}$, $\mathrm{Ba}, \mathrm{Sr} /(\mathrm{Ca}+\mathrm{K})$ and $\mathrm{Ba} /(\mathrm{Ca}+\mathrm{K})$ of rocks show concave-downward curves and scatter plotted against $\mathrm{SiO}_{2}$.

(4) Diorite to syenogranite have similar REE patterns and define a pseudo-errorchron.

(5) Syenogranitic magma evolved by fractional crystallization of plagioclase, microcline, edenite, biotite and titanite, which mainly explains the descent line in the $\mathrm{Zr}, \mathrm{Sr}, \mathrm{Ba}, \mathrm{Sr} /(\mathrm{Ca}+\mathrm{K})$ and $\mathrm{Ba} /(\mathrm{Ca}+\mathrm{K})$ variation diagrams.

(6) The major and trace element contents of quartzmonzonite, porphyritic quartz-monzonite, quartzmonzodiorite and quartz-syenite can be modelled by 
simple mixing between dioritic and syenogranitic magmas, and explain the linear trends and ascent line in $\mathrm{Zr}, \mathrm{Sr}, \mathrm{Ba}, \mathrm{Sr} /(\mathrm{Ca}+\mathrm{K})$ and $\mathrm{Ba} /(\mathrm{Ca}+\mathrm{K})$ diagrams of rocks.

(7) Diorite enclaves in the quartz-monzogranite may have been derived mainly by mingling/mixing of dioritic magma and quartz-monzogranitic magma, but mingling was dominant.

(8) Syenogranite and microsyenogranite correspond to two different pulses of granite magma as shown by their distinct initial ${ }^{87} \mathrm{Sr} /{ }^{86} \mathrm{Sr}$ ratios of $0.7075-0.7088$ and $0.7093-0.7117$, respectively.

(9) Pressure of crystallization ranges between 5.7 and $7.1 \mathrm{kbar}$ with an average value of $6 \mathrm{kbar}$. Temperatures estimated from amphibole-plagioclase geothermometer are $782-798{ }^{\circ} \mathrm{C}$ for syenogranitic magma and $785-850{ }^{\circ} \mathrm{C}$ for dioritic magma, which is rather low. Feldspars reequilibrated at $473-732{ }^{\circ} \mathrm{C}$ and actinolite crystallized under subsolidus conditions.

\section{Acknowledgements}

This paper corresponds to part of the $\mathrm{PhD}$ thesis of T.F.C. Campos. Grants PICD-CAPES and PDEECAPES given to T.F.C. Campos are gratefully acknowledged. Thanks are due to Dr. J. Esson for $\mathrm{XRF}$ and electron microprobe facilities at the Department of Earth Sciences, University of Manchester, UK; Dr. S.J. Parry for the facilities at the Nuclear Reactor Centre, Ascot, UK; Dr. M.J. Whitehouse and $\mathrm{Mr}$. R. Goodwin for the $\mathrm{Rb}-\mathrm{Sr}$ isotopic data obtained at the Department of Earth Sciences, University of Oxford, UK; and Institute of Geosciences of Federal University of Rio Grande do Sul, Brazil, for the wet chemical analyses. The critical reviews by Dr. C.G. Barnes and Dr. V.P. Ferreira are gratefully acknowledged. This research was carried out in the programme of Geosciences Centre, University of Coimbra, Portugal, and the programme of PostGraduation in Geosciences of Department of Geology of Federal University of Rio Grande do Sul, Brazil.

\section{References}

Almeida, F.F.M., Hasui, Y., Brito Neves, B.B., Fuck, R.A., 1981. Brazilian structural provinces: an introduction. Earth-Sci. Rev. $17,1-29$.
Barbarin, B., Didier, J., 1992. Genesis and evolution of mafic microgranular enclaves through various types of interaction between coexisting felsic and mafic magmas. Trans. R. Soc. Edin. Earth Sci. 83, 145-153.

Barnes, C.G., Burton, B.R., Burling, T.C., Wright, J.E., Karlson, H.R., 2001. Petrology and geochemistry of the late Eocene Harrison Pass Pluton, Ruby Mountains Core Complex, northeastern Nevada. J. Petrol. 42, 901-929.

Brandon, A.D., Creaser, R.A., Chacko, T., 1996. Constraints on rates of granitic magma transport from epidote dissolution kinetics. Sciences 271, 1845-1848.

Brown, G.C., 1981. Space and time in granite plutonism. Philos. Trans. R. Soc. Lond. Ser. A 301, 321-336.

Brown, G.C., Hugues, D.J., Esson, J., 1973. New XRF data retrieval techniques and their applications to U.S.G.S. standard rocks. Chem. Geol. 11, 223-229.

Campbell, I.H., Turner, J.S., 1985. Turbulent mixing between fluids with different viscosities. Nature 313, 39-42.

Campbell, I.H., Turner, J.S., 1986. The influence of viscosity on fountains in magma chamber. J. Petrol. 27, 1-30.

Campos, T.F.C., 1997. Geoquímica de rochas granitóides e seus minerais do batólito da Serra Negra do Norte-RN e Rio Espinharas-PB, nordeste do Brazil. Unpublished PhD thesis, Univ. Federal do Rio Grande do Sul, Porto Alegre, 408 pp.

Campos, T.F.C., Neiva, A.M.R., Nardi, L.S.V., 2000. Geochemistry of granites and their minerals from Serra Negra do Norte pluton, northeastern Brazil. Chem. Erde 60, 279-303.

Castro, A., Moreno-Ventas, I., de la Rosa, J.D., 1991. H-type (hybrid) granitoids: a proposed revision of the granite-type classification and nomenclature. Earth-Sci. Rev. 31, 237-253.

Collins, W.J., 1998. Evaluation of petrogenetic models for Lachlan Fold Belt granitoids: implications for crustal architecture and tectonic models. Aust. J. Earth Sci. 45, 483-500.

Collins, W.J., Richards, S.R., Healy, B.E., Ellison, P.I., 2000. Origin of heterogeneous mafic enclaves by two-stage hybridisation in magma conduits (dykes) below and in granitic magma chambers. Trans. R. Soc. Edin. Earth Sci. 91, 27-45.

Czamanske, G.K., Wones, D.R., 1973. Oxidation during magmatic differentiation, Finnmarka Complex, Oslo area, Norway: Part 2. The mafic silicates. J. Petrol. 14, 349-380.

D'Lemos, R.S., 1996. Mixing between granitic and dioritic crystal mushes, Guernsey, Channel Islands, U.K. Lithos 38, 233-257.

Droop, G.T.R., 1987. A general equation for estimating $\mathrm{Fe}^{3+}$ concentrations in ferromagnesian silicates and oxides from microprobe analyses, using stoichiometric criteria. Min. Mag. 51, 431-435.

Droop, G.T.R., 1994. Triple-chain pyriboles in Lewisian ultramafic rocks. Min. Mag. 58, 1-20.

Duchesne, J.-C., Berza, T., Liégeois, J.-P., Auwera, J.V., 1998. Shoshonitic liquid line of descent from diorite to granite: the Late Precambrian post-collisional Tismana pluton (South Carpathians, Romania). Lithos 45, 281-303.

Erlburg, M.A., 1996. Evidence of isotopic equilibration between microgranitoid enclaves and host granodiorite, Wasburton Granodiorite, Lachlan Fold Belt, Australia. Lithos 38, 1-22.

Ewart, A., 1982. The mineralogy and petrology of Tertiary-Recent orogenic volcanic rocks with special reference to the andesite- 
basaltic composition range. In: Thorpe, R.S. (Ed.), Andesites. Wiley, Chichester, UK, pp. 25-87.

Ferreira, V.P., Sial, A.N., Sá, E.F.J., 1998. Geochemical and isotopic signatures of Proterozoic granitoids in terranes of the Borborema structural province, northeastern Brazil. J. South Am. Earth Sci. 11, 439-455.

Foley, S.F., Venturelli, G., Green, D.H., Toscani, L., 1987. The ultrapotassic rocks: characteristics, classification and constraints for petrogenetic models. Earth Sci. Rev. 24, 81-134.

Foster, M.D., 1960. Interpretation of the composition of trioctahedral micas. U. S. Geol. Surv. Prof. Pap. 354 B, 1-49.

Fourcade, S., Allègre, C.J., 1981. Trace element behaviour in granitic genesis: a case study, the calc-alkaline plutonic association from the Querigut Complex, Pyrénées, France. Contrib. Mineral. Petrol. 76, 177-195.

Frost, T.P., Mahood, G.A., 1987. Field, chemical and physical constraints on mafic-felsic magma interaction in the Lamarck granodiorite, Sierra Nevada, California. Geol. Soc. Amer. Bull. 99, $272-291$.

Furhman, M.L., Lindsley, D.H., 1988. Ternary feldspars, modelling and thermometry. Am. Mineral. 73, 201-215.

Galindo, A.C., Dall'Agnol, R., McReath, I., Scheller, T., 1991. Granitóide Tourão, um batólito subalcalino Brasiliano no Nordeste do Rio Grande do Norte. XIV Simp. Geol. Nordeste B12, 201-215.

Galindo, A.C., Dall'Agnol, R., McReath, I., Lafon, J.M., Teixeira, N., 1995. Evolution of Brasiliano-age granitoid types in a shearzone environment, Umarizal-Caraúbas region, Rio Grande do Norte, Northeastern Brasil. J. South Am. Earth Sci. 8, 79-95.

Gonzalez, M.G.B., 1984. Geologia e petrologia da área da Serra Negra do Norte RN/PB. Unpublished MSc thesis, Federal Univ. Pará, Belém, Brazil, 137 pp.

Guimarães, I.P., Silva Filho, A.F., 1998. Nd and Sr isotopic geochronologic constraints for the evolution of the shoshonitic Brasiliano Bom Jardim and Toritama complexes: evidence for a Transamazinian enriched mantle under Borborema tectonic province. Int. Geol. Rev. 40/6, 500-527.

Guimarães, I.P., Silva Filho, A.F., 2000. Evidence of multiple sources involved in the genesis of the Neoproterozoic Itapetim granitic complex, NE Brazil, based on geochemical and isotopic data. J. South Am. Earth Sci. 13, 561-586.

Holland, T., Blundy, J., 1994. Non-ideal interactions in calcic amphiboles and their bearing on amphibole-plagioclase thermometer. Contrib. Mineral. Petrol. 116, 433-447.

Innocent, F., Manetti, P., Mazzuoli, R., Pasquare, G., Villari, G., 1982. Anatolia and north-western Iran. In: Thorpe, R.S. (Ed.), Andesites. Wiley, Chichester, pp. 327-341.

Keane, S.D., Morrison, J., 1997. Distinguishing magmatic from subsolidus epidote: laser probe oxygen isotope compositions. Contrib. Mineral. Petrol. 126, 265-274.

Le Bas, M.J., Streckeisen, A.L., 1991. The IUGS systematics of igneous rocks. J. Geol. Soc. (Lond.) 148, 825-833.

Leake, B.E., Wooley, A.R., Arps, C.E.S., Birch, W.D., Gilbert, M.C., Grice, J.D., Hawthorne, F.C., Kato, A., Kisch, H.J., Krivovichev, V.G., Linthout, K., Laird, J., Mandarino, J. Maresch, W.V., Nickel, E.H., Rock, N.M.S., Schumacher, J.C., Smith, D.C., Stephenson, N.C.N., Ungaretti, L., Whitaker, E.J.W.,
Youzhi, G., 1997. Nomenclature of amphiboles: report of the Subcommittee on Amphiboles of the International Mineralogical Association Commission on New Minerals and Mineral Names. Min. Mag. 61, 295-321.

Lesher, C.E., 1994. Kinetics of $\mathrm{Sr}$ and $\mathrm{Nd}$ exchange in silicate liquids: theory, experiments, and applications to uphill diffusion, isotopic equilibration, and irreversible mixing of magmas. J. Geophys. Res. 99, 9585-9604.

Maas, R., Nicholls, I.A., Legg, C., 1997. Igneous and metamorphic enclaves in the S-type Deddick Granodiorite, Lachlan Fold Belt, SE Australia: petrographic, geochemical, and $\mathrm{Nd}-\mathrm{Sr}$ isotopic evidence for crustal melting and magma mixing. J. Petrol. 38, 815-841.

Maniar, P.D., Piccoli, P.M., 1989. Tectonic discrimination of granitoids. Geol. Soc. Amer. Bull. 101, 635-643.

Mariano, G., Sial, A.N., Cruz, M.J.M., Conceição, H., 1996. The potassic calc-alkaline Itaporonga batholith, NE Brazil: mineral chemistry and oxygen-isotope data. Int. Geol. Rev. 38, 74-86.

McMurry, J., Long, L.E., Sial, A.N., 1987a. Petrology and isotope systematic of magma mushes: some porphyritic granitoids of northeastern Brazil. Rev. Bras. Geociências 17-4, 473-480.

McMurry, J., Long, L.E., Sial, A.N., 1987b. Evolution of heterogeneous, continentally derived granite: Dona Inês pluton, northeastern Brazil. J. Geol. 95, 107-117.

Morimoto, N., Fabries, J., Ferguson, A.K., Ginzbug, I.V., Ross, M., Seifert, F.A., Zussman, J., 1989. Nomenclature of pyroxenes. Can. Mineral. 27, 143-156.

Neves, S.P., Vauchez, A., 1995. Successive mixing and mingling of magmas in a plutonic complex of Northeast Brazil. Lithos 34, $275-299$.

Nockolds, S.R., 1947. The relation between chemical composition and paragenesis in the biotite micas of igneous rocks. Am. J. Sci. 245, 401-420.

Peccerillo, A., Taylor, S.R., 1976. Geochemistry of Eocene calcalkaline volcanic rocks from the Kastamanonu area, northern Turkey. Contrib. Mineral. Petrol. 58, 63-81.

Poli, G., Tommasini, S., 1991. Model of the origin and significance of microgranular enclaves in calc-alkaline granitoids. J. Petrol. 32, $657-666$.

Rickwood, P.C., 1989. Boundary line within petrological diagrams which use oxides of major and minor elements. Lithos 22, 247-263.

Robinson, P., Jaffe, H.W., Ross, M., Klein Jr., C. 1971. Orientation and exsolution lamellae in clinopyroxenes and clinoamphiboles: consideration of optimal phases boundaries. Am. Mineral. 56, 909-939.

Rollison, H.R., 1995. Using Geochemical Data: Evaluation, Presentation and Interpretation. Longman, UK, $352 \mathrm{pp}$.

Sabatier, H., 1991. Vaugnerites: special lamprophyre-derived mafic enclaves in some Hercynian granites from Western and Central Europe. In: Didier, J., Barbarin, B. (Eds.), Enclaves and Granite Petrology. Elsevier, Amsterdam, pp. 63-81.

Schmidt, M.A., 1992. Amphibole composition in tonalite as a function of pressure: an experimental calibration of the Al-in-hornblende barometer. Contrib. Mineral. Petrol. 110, 304-310.

Sial, A.N., Toselli, A.J., Saavedra, J., Parada, M.A., Ferreira, V.P., 1999. Emplacement, petrological and magnetic susceptibility 
characteristics of diverse magmatic epidote-bearing granitoid rocks in Brazil, Argentina and Chile. Lithos 46, 367-392.

Silva, M.M.V.G., Neiva, A.M.R., Whitehouse, M.J., 2000. Geochemistry of enclaves and host granites from the Nelas area, central Portugal. Lithos 50, 153-170.

Tindle, A.G., Pearce, J.A., 1981. Petrogenetic modelling of in situ fractional crystallization in the zoned Loch Doon Pluton, Scotland. Contrib. Mineral. Petrol. 78, 111-117.

Van der Laan, S.R., Wyllie, P.Y., 1993. Experimental interaction of granitic and basaltic magmas and implications for mafic enclaves. J. Petrol. 34, 491-518.

Waight, T.E., Maas, R., Nicholls, I.A., 2001. Geochemical investigations of microgranitoid enclaves in the S-type Cowra Granodiorite, Lachlan Fold Belt, SE Australia. Lithos 56, 165-186.

Wall, V.J., Clemens, J.D., Clark, D.B., 1987. Models for granitoid evolution and source compositions. J. Geol. 95, 731-749.
Watson, E.B., Harrison, T.M., 1983. Zircon saturation revisited: temperature and composition effects in a variety of crustal magma types. Earth Planet. Sci. Lett. 64, 295-304.

Whitehouse, M.J., 1990. Isotopic evolution of the southern Outer Hebridean Lewision gneiss complex: constraints on Late Archean source regions and the generation of transposed $\mathrm{Pb}-\mathrm{Pb}$ palaeoischrons. Chem. Geol., Isot. Geosci. Sect. 86, 1-20.

Zen, E.-An., Hammarstrom, J.M., 1984. Magmatic epidote and its petrological significance. Geology 12, 515-518.

Zen, E.-An., Hammarstrom, J.M., 1988. Plumbing the depth of pluton by magmatic epidote-hornblende association: a cautionary review an example from Round Valley Pluton, Western Idaho. Abstr. Programs - Geol. Soc. Am. 20, 475-476.

Zorpi, M.J., Coulon, C., Orsini, J.B., 1991. Hybridisation between felsic and mafic magmas in calc-alkaline granitoids - a case study in northern Sardinia, Italy. Chem. Geol. 92, 45-86. 